\title{
SELECTED AQUATIC BIOLOGICAL INVESTIGATIONS \\ IN THE GREAT SALT LAKE BASINS, 1875-1998, \\ NATIONAL WATER-QUALITY ASSESSMENT PROGRAM
}

By Elise M. Giddings and Doyle Stephens

\section{U.S. GEOLOGICAL SURVEY}

Water-Resources Investigations Report 99-4132

National Water-Quality Assessment Program

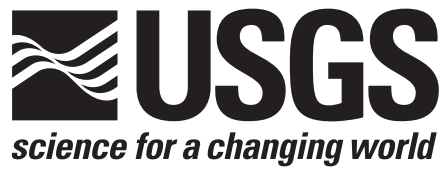

Salt Lake City, Utah 1999 


\section{U.S. DEPARTMENT OF THE INTERIOR \\ BRUCE BABBITT, Secretary}

U.S. GEOLOGICAL SURVEY

Charles G. Groat, Director 


\section{FOREWORD}

The mission of the U.S. Geological Survey (USGS) is to assess the quantity and quality of the earth resources of the Nation and to provide information that will assist resource managers and policymakers at Federal, State, and local levels in making sound decisions. Assessment of water-quality conditions and trends is an important part of this overall mission.

One of the greatest challenges faced by water-resources scientists is acquiring reliable information that will guide the use and protection of the Nation's water resources. That challenge is being addressed by Federal, State, interstate, and local water-resource agencies and by many academic institutions. These organizations are collecting waterquality data for a host of purposes that include: compliance with permits and water-supply standards; development of remediation plans for specific contamination problems; operational decisions on industrial, wastewater, or watersupply facilities; and research on factors that affect water quality. An additional need for water-quality information is to provide a basis on which regional- and national-level policy decisions can be based. Wise decisions must be based on sound information. As a society, we need to know whether certain types of water-quality problems are isolated or ubiquitous, whether there are significant differences in conditions among regions, whether the conditions are changing over time, and why these conditions change from place to place and over time. The information can be used to help determine the efficacy of existing water-quality policies and to help analysts determine the need for and likely consequences of new policies.

To address these needs, the U.S. Congress appropriated funds in 1986 for the USGS to begin a pilot program in seven project areas to develop and refine the National Water-Quality Assessment (NAWQA) Program. In 1991, the USGS began full implementation of the program. The NAWQA Program builds upon an existing base of waterquality studies of the USGS, as well as those of other Federal, State, and local agencies. The objectives of the NAWQA Program are to:

- Describe current water-quality conditions for a large part of the Nation's freshwater streams, rivers, and aquifers.

- Describe how water quality is changing over time.

- Improve understanding of the primary natural and human factors that affect water-quality conditions.

This information will help support the development and evaluation of management, regulatory, and monitoring decisions by other Federal, State, and local agencies to protect, use, and enhance water resources.

The goals of the NAWQA Program are being achieved through ongoing and proposed investigations of 59 of the Nation's most important river basins and aquifer systems, which are referred to as study units. These study units are distributed throughout the Nation and cover a diversity of hydrogeologic settings. More than two-thirds of the Nation's freshwater use occurs within the 59 study units and more than two-thirds of the people served by public water-supply systems live within their boundaries.

National synthesis of data analysis, based on aggregation of comparable information obtained from the study units, is a major component of the program. This effort focuses on selected water-quality topics using nationally consistent information. Comparative studies will explain differences and similarities in observed water-quality conditions among study areas and will identify changes and trends and their causes. The first topics addressed by the national synthesis are pesticides, nutrients, volatile organic compounds, and aquatic biology. Discussions on these and other water-quality topics will be published in periodic summaries of the quality of the Nation's ground and surface water as the information becomes available.

This report is an element of the comprehensive body of information developed as part of the NAWQA Program. The program depends heavily on the advice, cooperation, and information from many Federal, State, interstate, Tribal, and local agencies and the public. The assistance and suggestions of all are greatly appreciated.

Robert M. Hirsch

Chief Hydrologist 


\section{Contents}

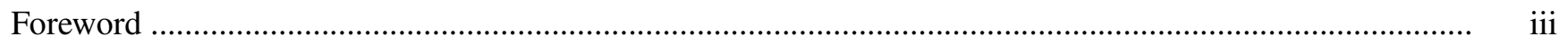

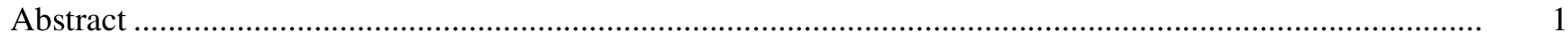

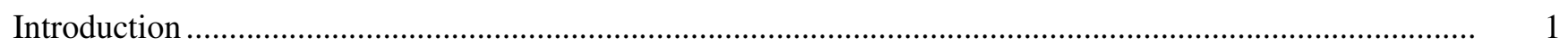

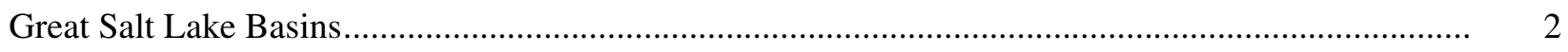

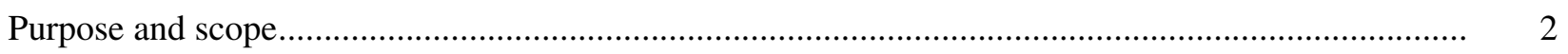

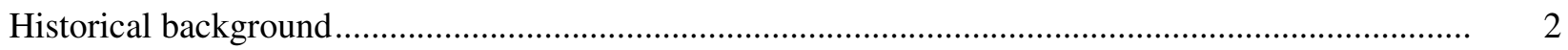

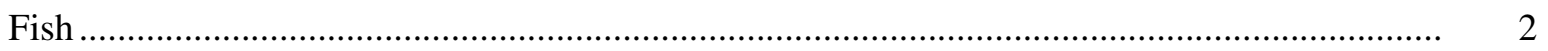

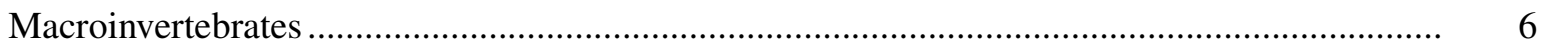

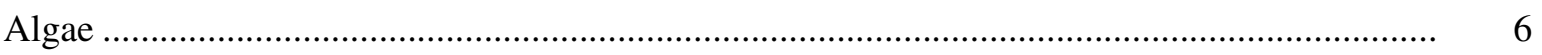

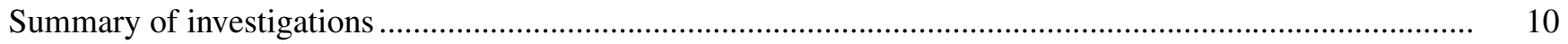

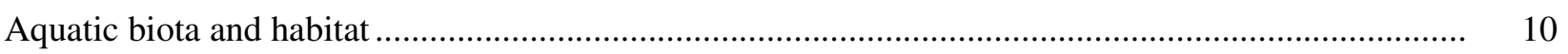

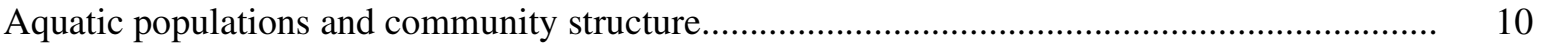

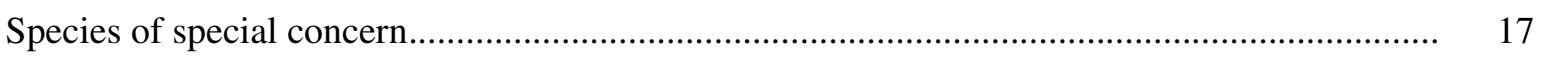

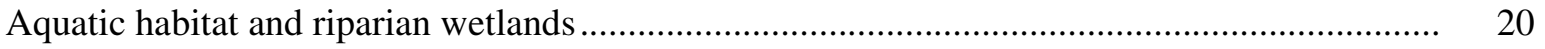

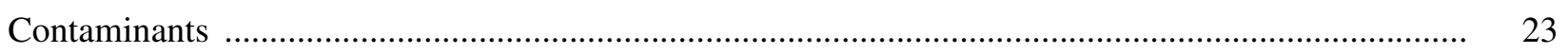

Utah Lake - Jordan River Basin ......................................................................................... 23

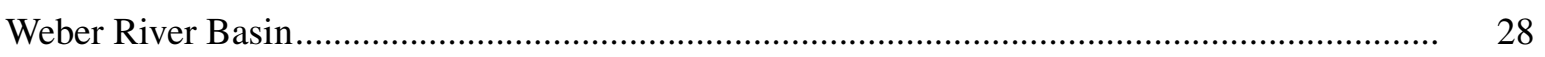

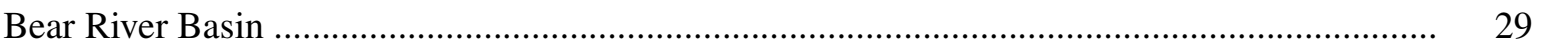

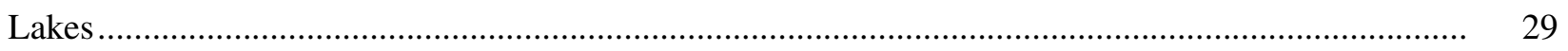

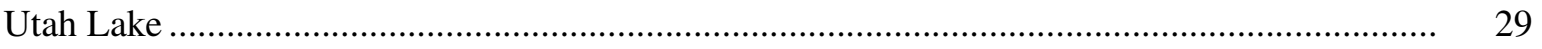

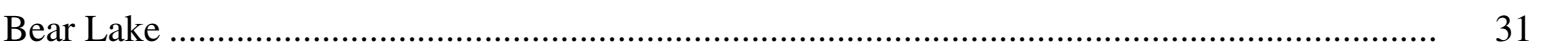

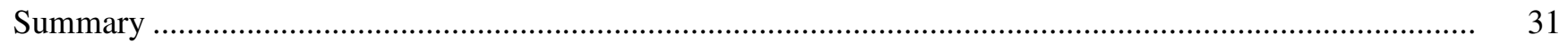

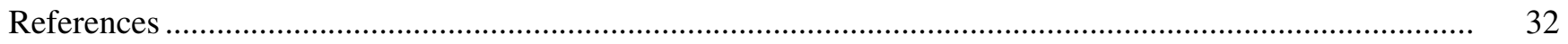

\section{FIGURES}

1-8. Maps showing:

1. Location of Great Salt Lake Basins study unit ...................................................................

2. Current and historical distribution of (a) Bonneville cutthroat trout, (b) June sucker, (c) least chub, (d) leatherside chub, and (e) spotted frog, in the Great Salt Lake Basins study unit . 7

3. Location of sites where macroinvertebrates have been or are currently monitored for waterquality assessments in the Great Salt Lake Basins study unit ................................................. 9

4. Location of studies of fish populations or surveys in the Great Salt Lake Basins study unit ...... 14

5. Location of studies of macroinvertebrate populations or surveys in the Great Salt Lake Basins study unit, excluding water-quality monitoring sites................................................ 15

6. Location of studies of algal populations in the Great Salt Lake Basins study unit ................... 16

7. Location of studies of aquatic habitat in the Great Salt Lake Basins study unit ....................... 22

8. Location of studies of contaminants in sediments or fish tissues in the Great Salt Lake Basins study unit. 
1. Fish species present in the Great Salt Lake Basins study unit ...................................................

2. Selected investigations of the populations and interactions of fish, macroinvertebrates, and algae in the Great Salt Lake Basins study unit........................................................................... 11

3. Selected investigations of aquatic species of special concern in the Great Salt Lake Basins

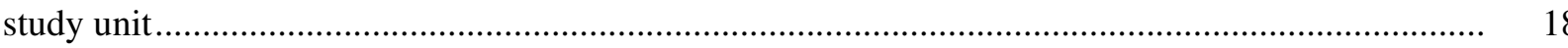

4. Selected investigations of aquatic habitat and riparian wetlands in the Great Salt Lake Basins study unit

5. Selected investigations of the presence and effects of contaminants in sediments or fish tissue

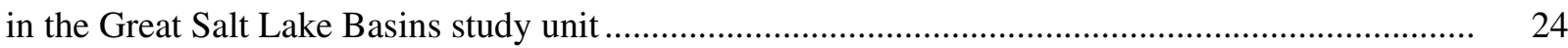

6. Selected investigations of Utah Lake and Bear Lake in the Great Salt Lake Basins study unit ......... 30

\section{CONVERSION FACTORS, VERTICAL DATUM, AND ABBREVIATED WATER-QUALITY UNITS}

\begin{tabular}{rll}
\hline Multiply & By & To obtain \\
\hline & & \\
mile & 1.609 & kilometer \\
square mile & 2.59 & square kilometer \\
\hline
\end{tabular}

Water temperature is reported in degrees Celsius $\left({ }^{\circ} \mathrm{C}\right)$, which can be converted to degrees Fahrenheit $\left({ }^{\circ} \mathrm{F}\right)$ by the following equation:

$$
{ }^{\circ} \mathrm{F}=1.8\left({ }^{\circ} \mathrm{C}\right)+32 .
$$

Sea level: In this report "sea level" refers to the National Geodetic Vertical Datum of 1929-a geodetic datum derived from a general adjustment of the first-order level nets of the United States and Canada, formerly called Sea Level Datum of 1929.

Chemical concentration and water temperature are reported only in metric units. Chemical concentration in water is reported in milligrams per liter $(\mathrm{mg} / \mathrm{L})$ or micrograms per liter $(\mu \mathrm{g} / \mathrm{L})$. Milligrams per liter is a unit expressing the solute per unit volume (liter) of water and is about the same as parts per million unless concentrations are greater than 7,000 milligrams per liter. One thousand micrograms per liter is equivalent to 1 milligram per liter. Chemical concentration in sediment and biological tissues is reported in micrograms per gram $(\mu \mathrm{g} / \mathrm{g})$, which is equal to parts per million ( $\mathrm{ppm})$, or micrograms per kilogram $(\mu \mathrm{g} / \mathrm{kg})$, which is equal to parts per billion (ppb). The units milligrams per kilogram $(\mathrm{mg} / \mathrm{kg})$ are equivalent to micrograms per gram $(\mu \mathrm{g} / \mathrm{g})$.

To compare dry-weight tissue concentration to wet weight, the equation is:

wet weight $=$ dry weight concentration $\mathrm{x}[1-($ percent moisture/100) $]$. 


\title{
SELECTED AQUATIC BIOLOGICAL INVESTIGATIONS IN THE GREAT SALT LAKE BASINS, 1875-1998, NATIONAL WATER- QUALITY ASSESSMENT PROGRAM
}

\author{
By Elise M. Giddings and Doyle Stephens
}

\section{ABSTRACT}

This report summarizes previous investigations of aquatic biological communities, habitat, and contaminants in streams and selected large lakes within the Great Salt Lake Basins study unit as part of the U.S. Geological Survey's National Water-Quality Assessment Program (NAWQA). The Great Salt Lake Basins study unit is one of 59 such units designed to characterize water quality through the examination of chemical, physical, and biological factors in surface and ground waters across the country. The data will be used to aid in the planning, collection, and analysis of biological information for the NAWQA study unit and to aid other researchers concerned with water quality of the study unit.

A total of 234 investigations conducted during 1875-1998 are summarized in this report. The studies are grouped into three major subjects: (1) aquatic communities and habitat, (2) contamination of streambed sediments and biological tissues, and (3) lakes. The location and a general description of each study is listed. The majority of the studies focus on fish and macroinvertebrate communities. Studies of algal communities, aquatic habitat, riparian wetlands, and contamination of streambed sediment or biological tissues are less common. Areas close to the major population centers of Salt Lake City, Provo, and Logan, Utah, are generally well studied, but more rural areas and much of the Bear River Basin are lacking in detailed information, except for fish populations.

\section{INTRODUCTION}

In 1991, the U.S. Geological Survey (USGS) began full-scale implementation of the National WaterQuality Assessment (NAWQA) Program. The objectives of the NAWQA program are to (1) describe the status and trends in water-quality conditions of a large part of the Nation's surface and ground waters, and (2) improve understanding of the primary natural and human factors that affect water-quality conditions (Gilliom and others, 1995). This information will be used to plan future water-management actions and assess their likely consequences. The NAWQA program is designed to address water-quality issues at multiple scales. The Great Salt Lake Basins (GSLB) study unit is 1 of 59 proposed study units that are the building blocks of the program. Information from all the study units will be aggregated to assess regional and national water-quality issues.

One of the primary goals of the NAWQA program is to develop a better understanding of the interactions among physical, chemical, and biological characteristics of streams in selected environmental settings (Gurtz, 1994). Ecological studies are included in the NAWQA program to provide data on biological communities that contribute to the understanding of this interaction. In addition, biological communities can, in themselves, be good indicators of water quality. Studies of organic and inorganic contamination of fish tissues and streambed sediments also are included in the NAWQA program to help understand the potential danger these contaminants pose to aquatic and terrestrial life. To aid in the interpretation of these studies, conditions of biological communities and contaminants are investigated in existing literature. This compilation of previous investigations will aid in understanding current water-quality status and trends in the study unit. 


\section{Great Salt Lake Basins}

The Great Salt Lake Basins study unit (fig. 1) encompasses three major river systems that enter Great Salt Lake: the Bear River in the northern part of the study unit, the Weber River in the central part, and the Utah Lake-Jordan River Basin in the southern part of the study unit. The Provo River and the Spanish Fork are large tributary drainages that terminate in Utah Lake. The Jordan River flows northward from Utah Lake through the Salt Lake City metropolitan area before discharging to Great Salt Lake. The study unit is 14,500 square miles in area and is mostly located in Utah, but also includes parts of southwestern Wyoming and southeastern Idaho. The study unit includes Utah's 3 largest cities, Salt Lake City, Ogden, and Provo, and about 1.4 million people, 85 percent of the State's population. Utah's population is expected to grow nearly 50 percent in the next 20 years, with most of the increase occurring in the study unit. Most of the study unit is forest and rangeland (70 percent), but 18 percent is agricultural and 3 percent is urban. Most of the agricultural land is irrigated.

\section{Purpose and Scope}

This report summarizes available investigations of aquatic biota and habitat in the GSLB study unit. Current and changing conditions of fish and macroinvertebrate populations in the study unit are discussed in general. Investigations summarized in this report are categorized into three major groups with subsections: (1) aquatic biota and habitat; (2) contaminants; and (3) lakes. This information will be used by the staff of the GSLB study unit to further develop the aquatic biology part of the program, and by other professionals and students working in the study unit.

Investigations included in this report examine fish, macroinvertebrates, algae, instream habitat, riparian wetlands, human effects on aquatic communities, contaminants and health of aquatic communities, and aquatic species of special concern. Literature on aquatic species of special concern is covered only briefly because special concern species are not a focus of the NAWQA program. Laboratory studies are not included, and studies on the control of mosquitoes also are not included. Although the focus of the NAWQA program is on rivers and not lakes, a short discussion of Utah and Bear Lakes is included in this report because of their importance to the river systems and the general public. Recent stream studies are included whenever possible. Some investigations published only in internal or informal documents may not be included.

Literature selected for inclusion is published in a variety of formats including journal articles and conference proceedings, government reports, university documents, theses, dissertations, and books. Investigations were carried out by university faculty and students, other Federal, State, and local government agencies, and environmental consulting firms.

\section{Historical Background}

\section{Fish}

The native fishery of the study unit is typical of the Basin and Range Province of the United States. It consists of about 17 native species of fish, many of which are endemic to the enclosed basins of the Western United States. Cutthroat trout and mountain whitefish are the most dominant native predatory fish. Utah Lake is noted in reports from early settlers for its abundance of trout, whitefish, and suckers, which were a major food source for pioneers (Cope and Yarrow, 1875; Jordan, 1891). Other species native to the study unit are listed in table 1, and include species of chubs, minnows, sculpins, and four species endemic to Bear Lake.

Stocking of exotic fish species began in earnest in 1881, with the stocking of carp throughout the State. The carp were stocked as an additional food source for settlers, and as part of a nationwide stocking program of food fishes (Holden and others, 1996). In the 1890s, sport fishing became popular and the fish species chosen for stocking reflected this trend. Game fish from around the country, as well as native cutthroat trout, were raised in hatcheries and introduced into the study unit. The stocking program in the State has continued to expand and game species of all types have been introduced, including other trout species and warm-water species such as bass, bluegill, and perch (table 1). 


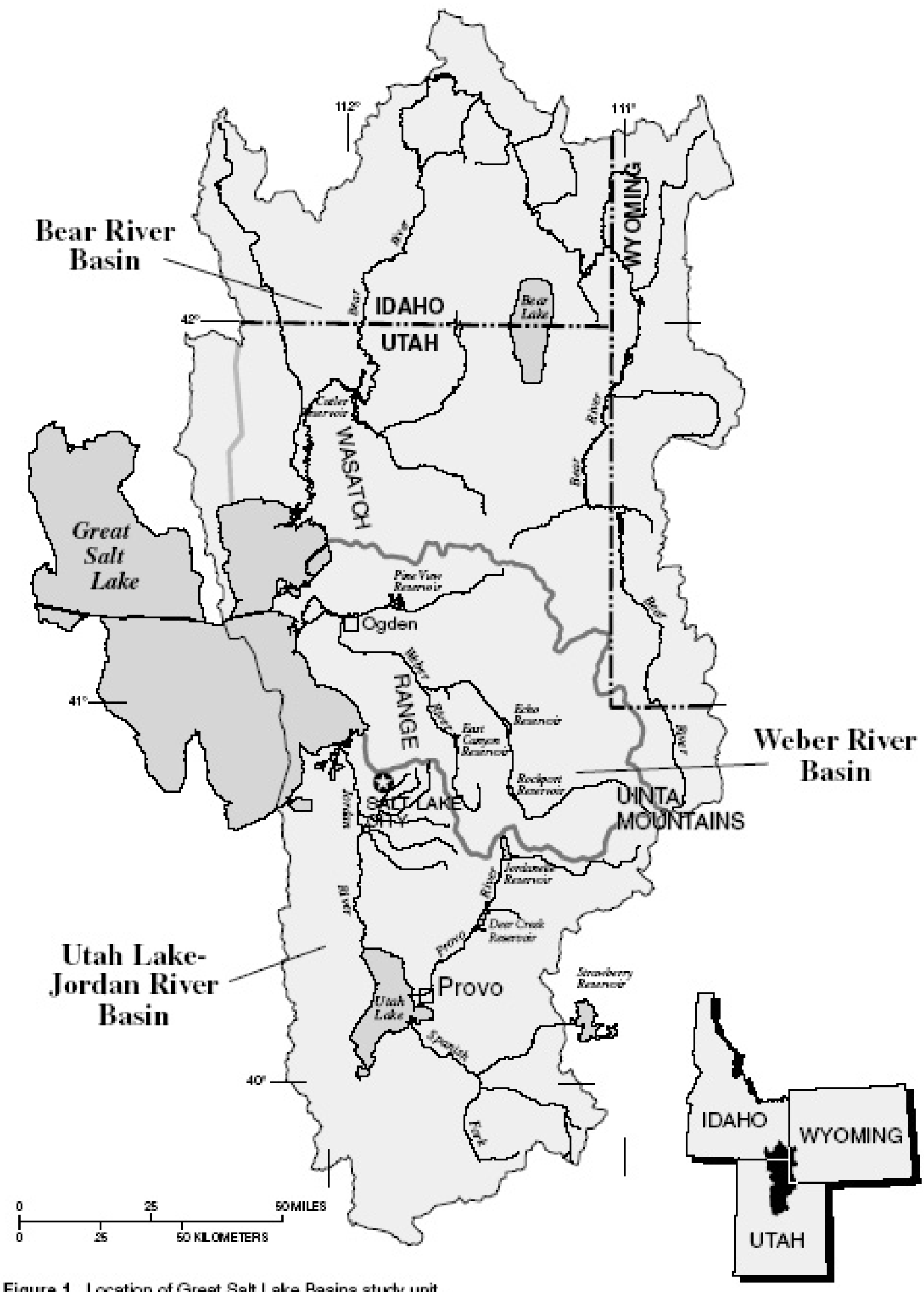

Figure 1. Location of Great Salt Lake Basins study unit. 
Table 1. Fish species present in the Great Salt Lake Basins study unit

\begin{tabular}{|c|c|c|}
\hline Family & Common name & Scientific name $^{1}$ \\
\hline \multicolumn{3}{|c|}{ NATIVE FISH } \\
\hline \multirow[t]{6}{*}{ Minnow family; Cyprinidae } & Utah chub & Gila atraria \\
\hline & Least chub & Iotichthys phlegethontis \\
\hline & Leatherside chub & Gila copei \\
\hline & Redside shiner & Richardsonius balteatus \\
\hline & Speckled dace & Rhinichthys osculus \\
\hline & Longnose dace & Rhinichthys cataractae \\
\hline \multirow[t]{4}{*}{ Sucker family; Catostomidae } & Utah sucker & Catostomus ardens \\
\hline & June sucker & Chasmistes liorus \\
\hline & Mountain sucker & Catostomus platyrhynchus \\
\hline & Bluehead sucker (Green sucker) & Catostomus discobolus \\
\hline \multirow[t]{5}{*}{ Trout and Whitefish family; Salmonidae } & Bonneville cutthroat trout & Oncorhynchus clarki utah \\
\hline & Mountain whitefish & Prosopium williamsoni \\
\hline & Bonneville whitefish $^{2}$ & Prosopium spilonotus \\
\hline & Bear Lake whitefish ${ }^{2}$ & Prosopium abyssicola \\
\hline & Bonneville cisco $^{2}$ & Prosopium gemmifer \\
\hline \multirow[t]{4}{*}{ Sculpin family; Cottidae } & Mottled sculpin & Cottus bairdi \\
\hline & Paiute sculpin & Cottus beldingi \\
\hline & Utah Lake scuplin (extinct) & Cottus echinatus \\
\hline & Bear Lake sculpin ${ }^{2}$ & Cottus extensus \\
\hline
\end{tabular}

\section{INTRODUCED FISH}

Herring family; Clupeidae

Minnow family; Cyprinidae

Sucker family; Catostomidae

Catfish family; Ictaluridae

Pike family; Esocidae
Gizzard shad

Common carp

Golden shiner

Fathead minnow

Goldfish

Grass carp

Spottail shiner

White sucker

Channel catfish

Black bullhead

Northern pike

Tiger muskie
Dorosoma cepedianum

Cyprinus carpio

Notemigonus crysoleucas

Pimephales promelas

Carassius auratus

Ctenopharyngodon idella

Notropis hudsonius

Catostomus commersoni

Ictalurus punctatus

Ameiurus melas

Esox lucius

Esox masquinongy $\mathrm{x}$ E. lucius 
Table 1. Fish species present in the Great Salt Lake Basins study unit-Continued

\begin{tabular}{|c|c|c|}
\hline Family & Common name & Scientific name ${ }^{1}$ \\
\hline \multicolumn{3}{|c|}{ INTRODUCED FISH-Continued } \\
\hline \multirow[t]{10}{*}{ Trout and Whitefish family; Salmonidae } & Kokanee & Oncorhynchus nerka \\
\hline & Yellowstone cutthroat trout & Oncorhynchus clarki lewisi \\
\hline & Cutthroat trout hybrids & Oncorhynchus clarki ssp. \\
\hline & Rainbow trout & Oncorhynchus mykiss \\
\hline & Brown trout & Salmo trutta \\
\hline & Brook trout & Salvelinus fontinalis \\
\hline & Golden trout & Oncorhynchus aguabonita \\
\hline & Lake trout & Salvelinus namaycush \\
\hline & Arctic grayling & Thymallus arcticus \\
\hline & Splake & Salvelinus namaycush $\mathrm{x}$ S. fontinalis \\
\hline \multirow[t]{2}{*}{ Killifish family; Cyprinodontidae } & Rainwater killifish & Lucania parva \\
\hline & Plains killifish & Fundulus zebrinus \\
\hline Livebearer family; Poeciliidae & Western mosquitofish & Gambusia affinis \\
\hline \multirow[t]{2}{*}{ Temperate bass family; Percichthyidae } & White bass & Morone chrysops \\
\hline & Wiper & Morone chrysops x M. saxatilis \\
\hline \multirow[t]{6}{*}{ Sunfish family; Centrarchidae } & Largemouth bass & Micropterus salmoides \\
\hline & Smallmouth bass & Micropterus dolomieu \\
\hline & Green sunfish & Lepomis cyanellus \\
\hline & Bluegill & Lepomis macrochirus \\
\hline & Sacramento perch & Archoplites interruptus \\
\hline & Black crappie & Pomoxis nigromaculatus \\
\hline \multirow[t]{2}{*}{ Perch family; Percidae } & Yellow perch & Perca flavescens \\
\hline & Walleye & Stizostedion vitreum \\
\hline
\end{tabular}

\footnotetext{
${ }^{1}$ Taxonomic classification follows Robins and others, 1991.

${ }^{2}$ These species are endemic to Bear Lake.
} 
Native fish species generally have declined as a result of the presence of exotic species and the destruction of fish habitats. Four of the original 17 native species in the Bonneville drainages are now considered endangered, sensitive, or rare: the Bonneville cutthroat trout, June sucker, least chub, and leatherside chub (fig. 2 ). The fish assemblage of Utah Lake has been greatly affected by the introduction of exotic species (Environmental Dynamics, 1975), and the original populations of cutthroat trout and suckers have declined dramatically, partly as a result of these introductions. Stocking efforts for native species have increased in recent years in an attempt to expand their distribution to historical ranges.

In contrast, introduced fish species have not thrived in Bear Lake. It is suspected that this is caused by a unique chemical environment and lack of habitat conducive to non-native fishes in the lake (Dave Beauchamp, Utah State University, oral commun., 1998). Four native species endemic only to Bear Lake dominate the community: Bear Lake whitefish, Bonneville whitefish, Bear Lake sculpin, and Bonneville cisco (Wurtsbaugh and Hawkins, 1990). In addition to these species, the native lake form of the Bonneville cutthroat trout and the exotic lake trout also are maintained through stocking programs.

\section{Macroinvertebrates}

Researchers began to focus on the macroinvertebrates of the region in the 1960s, and taxonomic keys and lists of species were produced for many groups, especially the stoneflies (Plecoptera) (for example Gaufin, 1964; Gaufin and others, 1966). Before the 1960s, studies of the macroinvertebrates tended to focus on their role as a food source for game fish. Many of the studies in the 1960s and 70s provide information on aquatic invertebrates with which current studies can be compared, at least for specific areas. However, the studies were often limited in time or space, so it is difficult to get a sense of trends in the macroinvertebrate community over time.

The Provo and Logan Rivers are the most studied rivers in the study unit, in addition to some streams along the Wasatch Front. The Brigham Young University Center for Health and Environmental Studies (1976) collected and analyzed macroinvertebrate data from the Provo River in 1976 in order to characterize the water quality of the river. This study was one of the first to use macroinvertebrates for water-quality assessment on a large scale. Hinshaw (1967) used macroinvertebrates as an indicator of declining water quality in the Jordan River during 1956-65.

The use of macroinvertebrates to monitor water quality has been gaining popularity in recent years. For example, the U.S. Forest Service has been collecting macroinvertebrate samples from streams on their lands to assess both water quality and food sources for fish (Paul Cowley, Wasatch National Forest, oral commun., 1998). State Departments of Environmental Quality (DEQ) also have incorporated the collection of macroinvertebrates as part of their routine sampling. In Idaho, both macroinvertebrate and periphyton samples are collected as part of a "beneficial use reconnaissance project" to rapidly characterize stream integrity and water quality (Idaho Department of Environmental Quality, 1998). The Wyoming DEQ also has started to collect macroinvertebrate and some periphyton samples to assess water quality in part of the Bear River basin (Jack Smith, Wyoming Department of Environmental Quality, oral commun., 1998). The Utah DEQ has collected macroinvertebrate samples at sites throughout the State, including the Great Salt Lake Basins study unit (Mangum, 1995). Sites where macroinvertebrates have been or are currently monitored for water-quality assessment are shown in figure 3 .

\section{Algae}

As with macroinvertebrates, algae studies are mostly limited to surveys and taxonomic lists and a few studies of the role of algae in stream dynamics. Norrington (1925) provided an early checklist of algae in the Wasatch and Uinta Mountains. McConnell and Sigler (1958) examined periphyton relations to macroinvertebrates, and Quinn (1958) used periphyton to document pollution from a sugar beet factory along the Jordan River. Although some monitoring efforts are in place to examine periphyton, algae populations continue to be neglected as a source of water-quality information. 
(a) Bonneville cutthroat trout

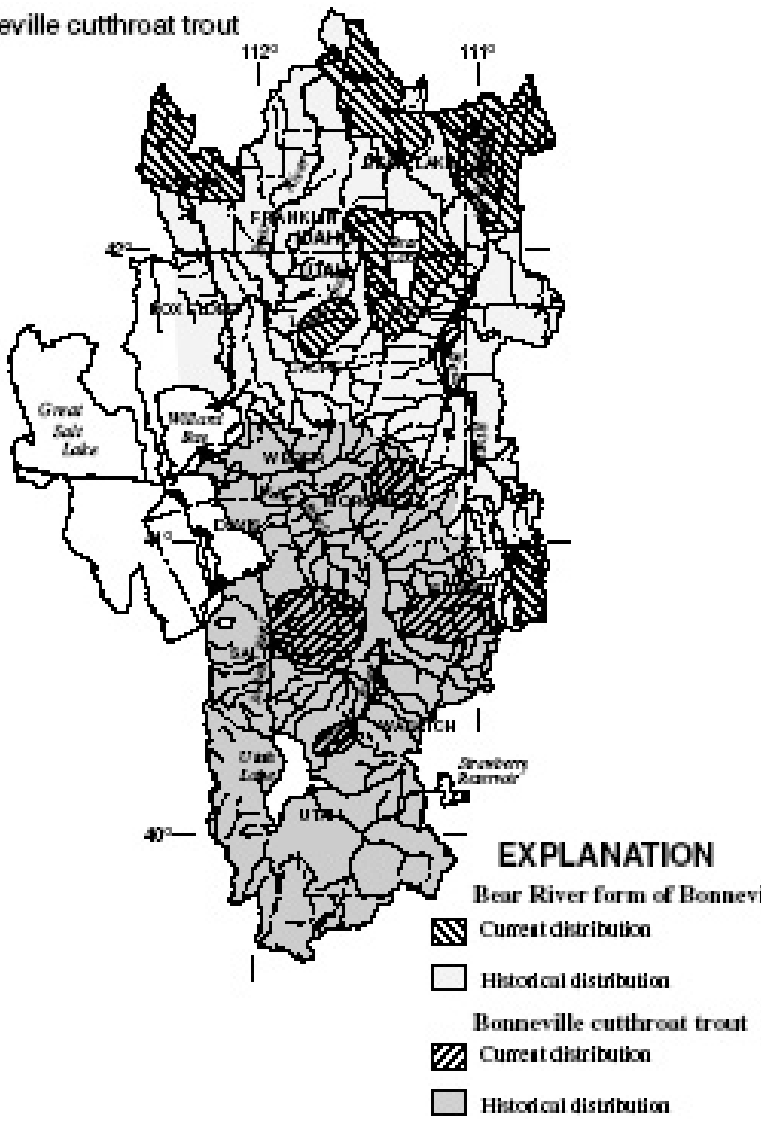

(c) Least chub

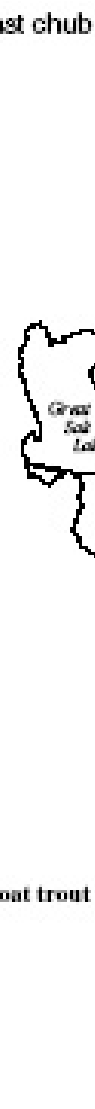

$111^{\circ}$

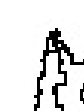

促 $\Rightarrow$ st now

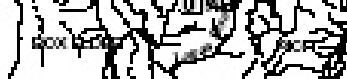

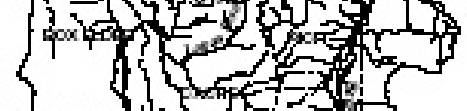

7 wan
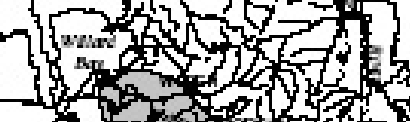
3 1420
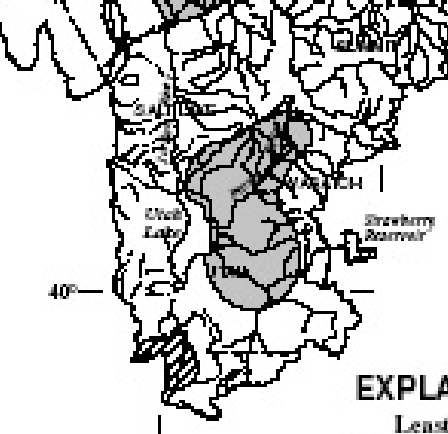

EXPLANATION Leas chub

Zु Curreat ditatritution

Hisborcal distributios

(b) June sucker
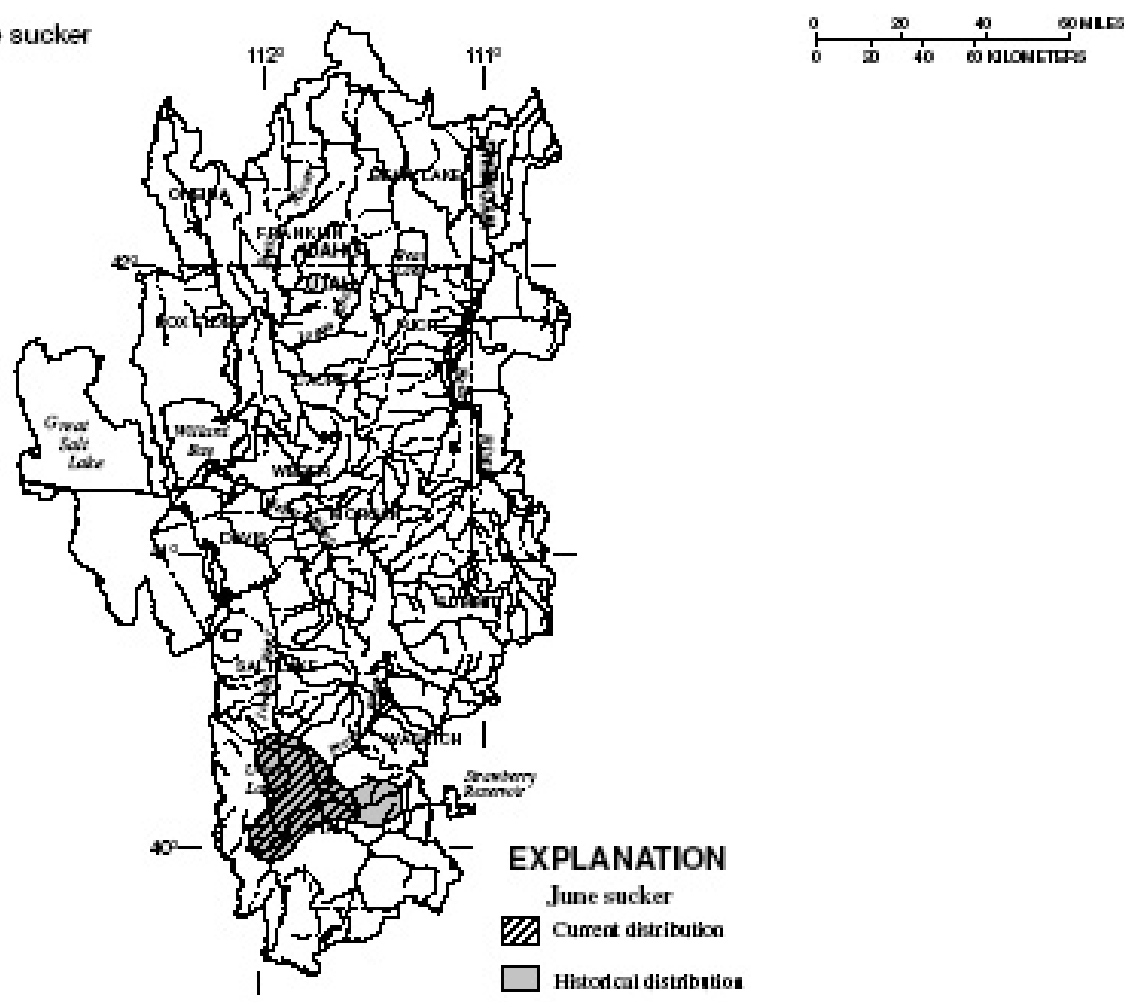

Figure 2. Current and historical distrbution of (a) Bonneville cutthroat trout, (b) June sucker, (c) least chub, (d) leatherside chub, and (e) spotted frog, in the Great Salt Lake Basins study unit. 
(d) Leatherside chub

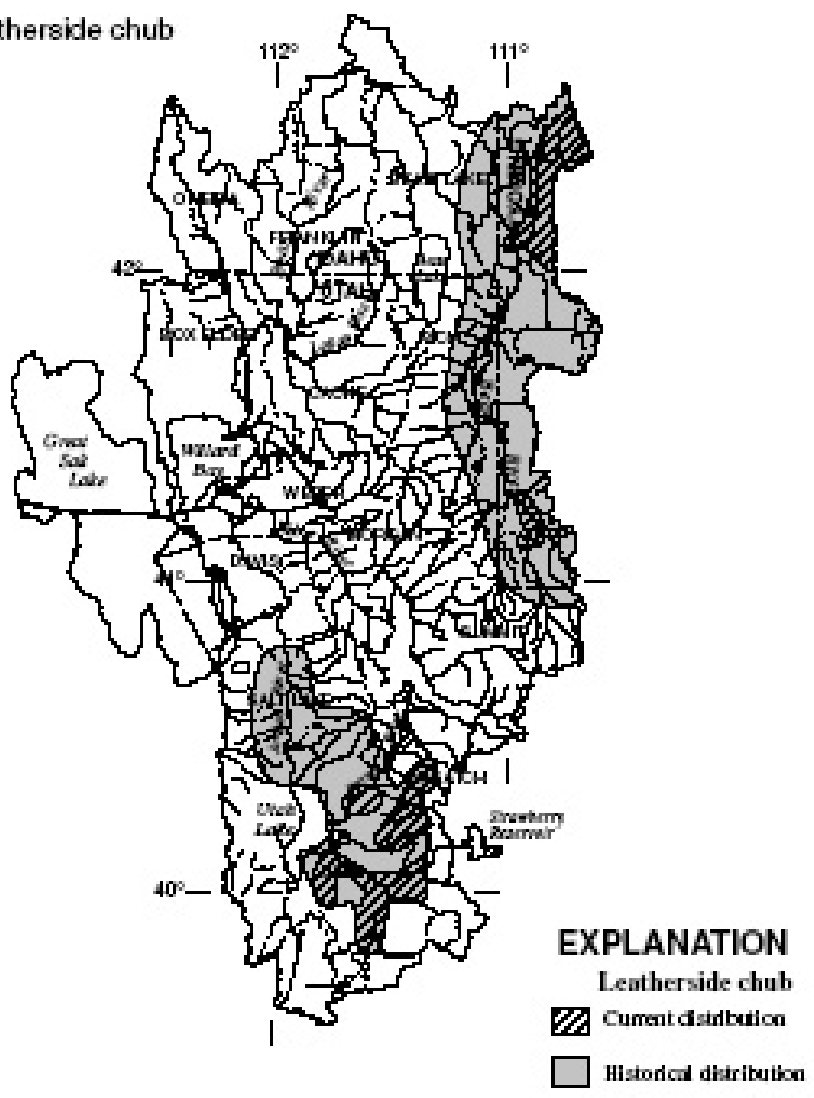

(e) Spotted frog
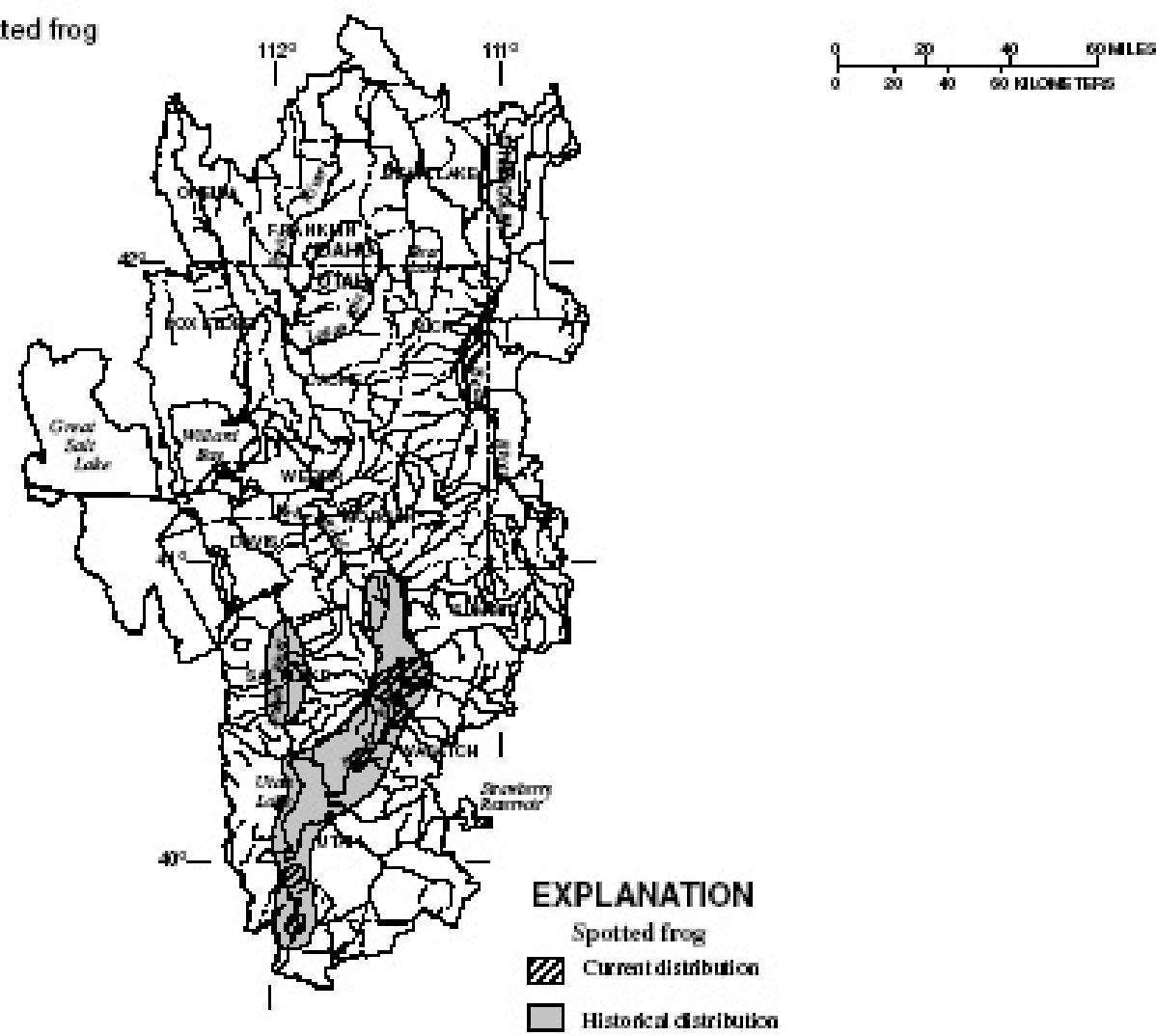

Figure 2. Current and historical distrbution of (a) Bonnevills cutthroat trout, (b) June sucker, (c) least chub, (d) leatherside chub, and (e) spotted frog, $n$ the Great Salt Lake Basins study unit - Continued. 


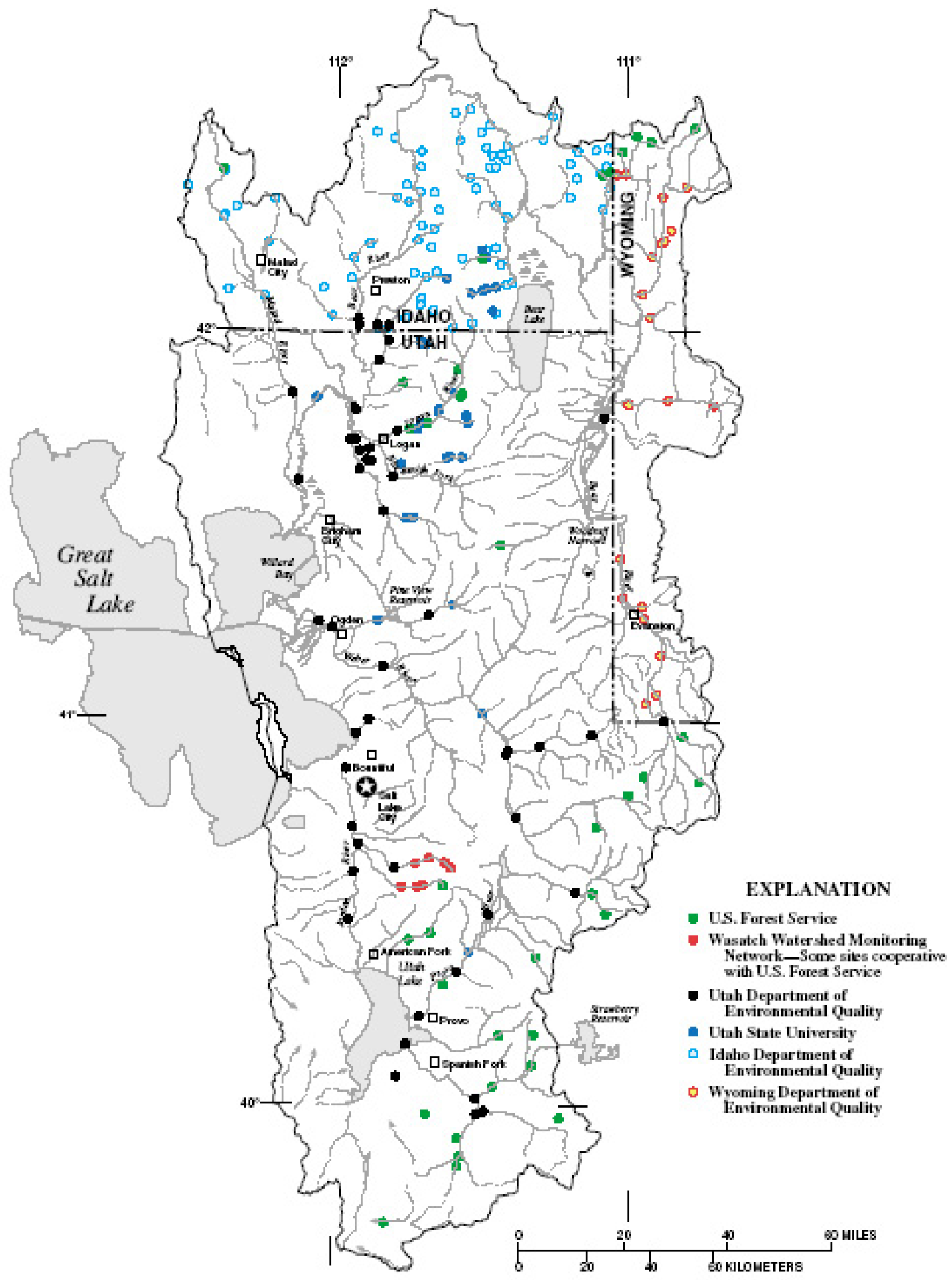

Figure 3. Location of sites where macroinvertebrates have been or are currently monitored for water-quality asesesments in the Great Salt Lake Basins study unit. 


\section{SUMMARY OF INVESTIGATIONS}

A selection of 234 studies conducted from 1875 to 1998 are summarized in this report. The studies are categorized into three groups, with subsections, by subject: (1) aquatic biota and habitat, (2) contamination of streambed sediment and biological tissues, and (3) Utah and Bear Lakes. A general description of each study is presented in tables 2 to 6 and locations of site-specific studies are shown in figures 4 to 8 . Some studies examine multiple aspects of aquatic biota (for example biotic communities and their contaminants) and are listed in more than one table or figure. The majority of the studies focus on fish and macroinvertebrate communities. Studies of algal communities, aquatic habitat, riparian wetlands, and contamination of streambed sediment or biological tissues are less common. Areas close to the major population centers of Salt Lake City, Provo, and Logan, Utah, are generally well studied, but more rural areas and much of the Bear River Basin are lacking in detailed information, except for fish populations.

Selected studies from each group are discussed below.

\section{Aquatic Biota and Habitat}

Studies of aquatic biological communities and their habitat represent most of the information that has been collected in the study unit. These studies have been further categorized into three sections: (1) aquatic populations and community structure, (2) species of special concern, and (3) aquatic habitat and riparian wetlands.

A few bibliographic compilations have been published that include the GSLB study unit. Christensen published a bibliography of aquatic biological studies conducted in Utah, which he later updated (Christensen, 1956; Christensen, 1962), and Rushforth and Merkley (1988) published a literature review of algal taxonomic studies.

\section{Aquatic Populations and Community Structure}

Studies of the aquatic populations and communities in streams generally consist of surveys of species assemblages, taxonomic descriptions, and ecological studies (table 2). Earlier studies focus on surveys of community composition and taxonomy. More recent studies emphasize the ecology of specific organisms or groups of organisms and how they relate to their environments. Information on fish (fig. 4) and macroinvertebrates (fig. 5) is extensive in some areas of the study unit and sparse in other areas. Information on algal populations is sparse throughout the study unit (fig. 6).

Fisheries have been important since the settlement of the West began. The first recorded information on fish communities in Utah comes from the Wheeler Geographical Survey in the natural historian's report (Cope and Yarrow, 1875). Shortly after that, a more extensive report on the fishes of Colorado and Utah was published by Jordan (1891). Tanner (1936) made the first survey of Utah fishes that included all waters of the State. All State fish and wildlife agencies have published books that commonly include the distribution of each fish taxa statewide, some life history notes, and information for anglers. Fishes of Utah was published in 1963 (Sigler and Miller), a revised Fishes of Wyoming in 1970 (Baxter and Simon), and a revised Fishes of Idaho in 1982 (Simpson and Wallace). Both Wyoming Fishes and Fishes of Utah have been updated recently (Baxter and Stone, 1995; Sigler and Sigler, 1996). Sigler and Sigler (1987) also published a comprehensive book on the Fishes of the Great Basin. In addition to current distribution, status, and life history notes for both native and exotic species, this book contains information on the history of fish stocking in the region. Holden and others (1996) also published a comprehensive report on the history, reasons for, and effects of fish stocking in Utah.

A number of studies have examined the life history of specific fish species. Most of these studies are related to salmonids (Sigler, 1951a; Sigler, 1951b; Bridges, 1963; Brown, 1972; Myers, 1972; Salevurakis, 1974) or endangered species, but nongame species have been examined in some cases. Studies have been done on Utah and bluehead suckers in the Weber River (Andreasen and Barnes, 1975), the leatherside chub in Utah (Johnson and others, 1995), dace species in the Weber River (Bulloch, 1969), Utah chub (Carbine, 1936), and carp (Sigler, 1955; Sigler, 1958).

Macroinvertebrates also have been examined through surveys and ecological studies. The Brigham Young University Center for Health and Environmental Studies (1976) surveyed macroinvertebrates in the Provo River and Diamond Fork and calculated 
Table 2. Selected investigations of the populations and interactions of fish, macroinvertebrates, and algae in the Great Salt Lake Basins study unit

[Subbasin 1, Bear River Basin; 2, Weber River Basin; 3, Jordan River Basin; 4, Provo River/Utah Lake Basin]

\begin{tabular}{|c|c|c|c|c|c|c|c|}
\hline $\begin{array}{l}\text { Map } \\
\text { number } \\
\text { (figs. } \\
4-6 \text { ) }\end{array}$ & Reference & $\begin{array}{l}\text { Sub- } \\
\text { basin }\end{array}$ & Fish & $\begin{array}{c}\text { Macro- } \\
\text { inver-te- } \\
\text { brates }\end{array}$ & Algae & Habitat & General description \\
\hline 1 & Adamus, 1975 & 3 & & $\mathrm{x}$ & & & Diversity of population and drift of benthic organisms related to environmental factors; Mill Creek \\
\hline 2 & Alstad, 1978 & all & & $\mathrm{x}$ & & & Distribution, diversity, and community characteristics of caddisflies; Utah \\
\hline 3 & Anderson, 1963 & 2 & & $\mathrm{x}$ & $\mathrm{x}$ & & Macroinvertebrate and algae relation to environmental setting; Smith and Morehouse Creek \\
\hline 4 & Andreasen and Barnes, 1975 & 2 & $\mathrm{x}$ & & & & Reproduction of two species of suckers; Weber River \\
\hline 5 & Bangerter, 1966 & 1 & $\mathrm{x}$ & & & & Fisheries investigation/survey; Blacksmith Fork \\
\hline 6 & Baumann, 1967 & 3 & & $\mathrm{x}$ & & & Taxonomy, distribution, and emergence patterns of stoneflies; Mill Creek and Big Cottonwood Creek \\
\hline 7 & Baxter and Stone, 1995 & 1 & $\mathrm{x}$ & & & & Fish distribution, status; Wyoming \\
\hline 8 & Beers, 1969 & 1 & & & $\mathrm{x}$ & & Energy flow in the stream benthos for algae and microbes; Logan River \\
\hline 9 & Behmer and Hawkins, 1986 & 1 & & $\mathrm{x}$ & & & Invertebrate populations in a shaded vs. unshaded section of stream; Blacksmith Fork \\
\hline 10 & Bergersen, 1973 & 1 & $\mathrm{x}$ & & & & Fish population response to cessation of domestic sewage discharge; Logan River \\
\hline 11 & Bernard, 1976 & 1 & $\mathrm{x}$ & & & & $\begin{array}{l}\text { Reproduction and movement of salmonids in different sections of stream; Spawn Creek (tributary to } \\
\text { Logan River) }\end{array}$ \\
\hline 12 & Bickel, 1977 & all & & $\mathrm{x}$ & & & Survey of endemic molluscs; Intermountain West \\
\hline 13 & Bridges, 1963 & 1 & $\mathrm{x}$ & & & & Movement, numbers, and survival of brown trout and mountain whitefish; Logan River \\
\hline 14 & Brigham Young University, 1976 & 1,4 & & $\mathrm{x}$ & & & Inventory and information about macroinvertebrates; Provo River, Blacksmith Fork, Little Bear River \\
\hline 15 & Brooks, 1955 & 4 & & $\mathrm{x}$ & & & $\begin{array}{l}\text { Life histories, taxonomic keys, and distribution of midges (Chironomidae); Provo River above Deer } \\
\text { Creek Reservoir }\end{array}$ \\
\hline 16 & Brown, 1935 & 1 & $\mathrm{x}$ & $\mathrm{x}$ & & $\mathrm{x}$ & $\begin{array}{l}\text { Physical, chemical, and biological descriptions; Logan River, Blacksmith Fork, Little Bear River on } \\
\text { Cache National Forest }\end{array}$ \\
\hline 17 & Brown, 1972 & 1 & $\mathrm{x}$ & & & & Life history of juvenile mountain whitefish; Logan River \\
\hline 18 & Bulloch, 1969 & 2 & $\mathrm{x}$ & & & $\mathrm{x}$ & Life history characteristics, taxonomy, and habitats of two dace species; Weber River \\
\hline 19 & Carbine, 1936 & all & $\mathrm{x}$ & & & & Life history characteristics of Tigoma ataria (chub); Great Basin \\
\hline 20 & Cather, 1974 & 3 & & $\mathrm{x}$ & & & Life history and general habits of six species of stoneflies; Mill Creek, Salt Lake County \\
\hline 21 & Christensen, 1962 & all & & & & & Bibliography of aquatic biology studies in Utah \\
\hline 22 & Clark, 1958 & 1 & & & $\mathrm{x}$ & & Phytoplankton population survey; Logan River \\
\hline 23 & Coombs, 1964 & $1,2,4$ & & & $\mathrm{x}$ & $\mathrm{x}$ & Survey of algal flora by habitat (rivers, springs, etc.); western Uinta Mountains \\
\hline 24 & Cope and Yarrow, 1875 & all & $\mathrm{x}$ & & & & Reports on collections of fish, oriented toward human use; parts of Western United States \\
\hline 25 & Cowley, 1994 & 1 & $\mathrm{x}$ & & & & Fish surveys; Caribou National Forest \\
\hline 26 & Cowley, 1995 & all & $\mathrm{x}$ & & & & Fish surveys; Wasatch-Cache National Forest \\
\hline 27 & Cowley, 1997a & all & $\mathrm{x}$ & & & & Fish surveys; Wasatch-Cache National Forest \\
\hline 28 & Cowley, 1997b & all & $\mathrm{x}$ & & & & Fish surveys; Wasatch-Cache National Forest \\
\hline 29 & Crist and Holden, 1991 & 3 & $\mathrm{x}$ & & & & Distribution and reproduction of fish; lower Jordan River \\
\hline 30 & EDAW, 1979 & 3 & $\mathrm{x}$ & & & & Fish population survey; Jordan River, Mill Creek, Little Cottonwood Creek, Big Cottonwood Creek \\
\hline 31 & Edmunds, 1954 & all & & $\mathrm{x}$ & & & Checklist of mayflies; Utah \\
\hline 32 & Environmental Dynamics, 1975 & 3 & $\mathrm{x}$ & $\mathrm{x}$ & $\mathrm{x}$ & & Baseline conditions of fish, invertebrates, and algae in Jordan River, some information on contaminants \\
\hline 33 & Erman, 1968 & 1 & & $\mathrm{x}$ & & & Occurrence and distribution of invertebrates; lower Logan River \\
\hline 34 & Gaufin, 1949 & 4 & & $\mathrm{x}$ & & & Examined productivity based on benthic fauna; North and South Forks Provo River \\
\hline 35 & Gaufin, 1955 & all & & $\mathrm{x}$ & & & Distribution and taxonomy of stoneflies; Utah \\
\hline 36 & Gaufin, 1959 & 4 & & $\mathrm{x}$ & & & $\begin{array}{l}\text { Quantitative and qualitative measure of benthic invertebrates as potential food source for trout; Provo } \\
\text { River }\end{array}$ \\
\hline
\end{tabular}


$\vec{\sim}$ Table 2. Selected investigations of the populations and interactions of fish, macroinvertebrates, and algae in the Great Salt Lake Basins study unit-Continued

\begin{tabular}{|c|c|c|c|c|c|c|c|}
\hline $\begin{array}{c}\text { Map } \\
\text { number } \\
\text { (figs. } \\
4-6 \text { ) }\end{array}$ & Reference & $\begin{array}{l}\text { Sub- } \\
\text { basin }\end{array}$ & Fish & $\begin{array}{c}\text { Macro- } \\
\text { inver-te- } \\
\text { brates }\end{array}$ & Algae & Habitat & General description \\
\hline 37 & Gaufin, 1964 & all & & $\mathrm{x}$ & & & Checklist of stoneflies; Intermountain West \\
\hline 38 & Gaufin and others, 1966 & all & & $\mathrm{x}$ & & & Distribution and taxonomy of stoneflies; Utah \\
\hline 39 & Geer, 1981 & 3 & $\mathrm{x}$ & & & & Trout fishery condition; Little Cottonwood Creek \\
\hline 40 & Graham, 1950 & all & & $\mathrm{x}$ & & & Taxonomy and some life history of adult midges; northern Utah \\
\hline 41 & Harvey, 1993 & 3 & $\mathrm{x}$ & $\mathrm{x}$ & & & Effects of trout on benthic assemblages in headwater streams; Wasatch Front \\
\hline 42 & Harvey and Marti, 1993 & 1 & & $\mathrm{x}$ & & & Predation on stream benthos by the Dipper (a bird); Wheeler Creek \\
\hline 43 & Holden and Crist, 1987 & 3 & $\mathrm{x}$ & $\mathrm{x}$ & & & Status and limiting factors of aquatic community; Jordan River \\
\hline 44 & Holden and others, 1996 & all & $\mathrm{x}$ & & & & History and effects of fish stocking; Utah \\
\hline 45 & Hovingh, 1981 & all & & $\mathrm{x}$ & & & History and distribution of leeches, molluscs, and amphibians; Intermountain West \\
\hline 46 & Hubbs and Miller, 1948 & all & $\mathrm{x}$ & & & & Regional dispersal of fish in glacial and post-glacial time; Great Basin including Bonneville basin \\
\hline 47 & Hubert, 1988 & 1 & & $\mathrm{x}$ & & & Survey of crayfish in Wyoming \\
\hline 48 & Jensen, 1985 & 3 & $\mathrm{x}$ & $\mathrm{x}$ & $\mathrm{x}$ & $\mathrm{x}$ & $\begin{array}{l}\text { Summarizes biological information collected and determines if streams are meeting use designations; } \\
\text { Mill Creek, Little and Big Cottonwood Creeks valley reaches }\end{array}$ \\
\hline 49 & Jensen, 1990 & 3 & & $\mathrm{x}$ & & & Monitoring of invertebrates; Mill Creek, Little and Big Cottonwood Creeks \\
\hline 50 & Jensen, 1991 & 3 & & $\mathrm{x}$ & & & Monitoring of invertebrates; Mill Creek, Little and Big Cottonwood Creeks \\
\hline 51 & Johnson, 1985 & all & & $\mathrm{x}$ & & & Survey of crayfish in Utah \\
\hline 52 & Johnson and others, 1995 & all & $\mathrm{x}$ & & & & Life history characteristics of leatherside chub \\
\hline 53 & Jordan, 1891 & all & $\mathrm{x}$ & & & & Reports on collections of fish in 1889 ; Utah and Colorado \\
\hline 54 & Knowlton and Harmston, 1938 & all & & $\mathrm{x}$ & & & Checklist of Plecoptera and Trichoptera; Utah \\
\hline 55 & Lawson and Rushforth, 1975 & 4 & & & $\mathrm{x}$ & & Taxonomy and range of diatoms; Provo River \\
\hline 56 & Lium, 1969 & 2,4 & & $\mathrm{x}$ & & $\mathrm{x}$ & $\begin{array}{l}\text { Aquatic insect community composition in relation to habitats (fast and slow pools, fast riffles and cas- } \\
\text { cades); Uinta Mountains }\end{array}$ \\
\hline 57 & Madsen, 1931 & 3 & & $\mathrm{x}$ & & & List and taxonomy of invertebrates; City Creek \\
\hline 58 & Mangum, 1995 & all & & $\mathrm{x}$ & & & Monitoring of macroinvertebrates, yearly report; Utah \\
\hline 59 & Matthews and Neuhold, 1967 & 1 & $\mathrm{x}$ & & & & Movement of fish in relation to stream flows and temperature; lower Logan River \\
\hline 60 & McArthur and Barnes, 1988 & 4 & & $\mathrm{x}$ & & & Invertebrate community dynamics in process of leaf litter breakdown; North Fork Provo River \\
\hline 61 & McConnell and Sigler, 1958 & 1 & & $\mathrm{x}$ & $\mathrm{x}$ & & Spatial and temporal variability of chlorophyll levels and standing crops of insects; Logan River \\
\hline 62 & Merkley, 1948 & 4 & & $\mathrm{x}$ & & & Taxonomy of adult caddisflies; Provo River \\
\hline 63 & Meyers, 1972 & 1 & $\mathrm{x}$ & & & & Feeding habits of brown trout and whitefish; Logan River \\
\hline 64 & Miller, 1960 & all & $\mathrm{x}$ & & & & Changes in fish fauna as related to human activities; American Southwest \\
\hline 65 & Miller, 1977 & 1 & $\mathrm{x}$ & & & & Fish surveys; Bear River drainage in Wyoming \\
\hline 66 & Moffett, 1935 & 3 & & $\mathrm{x}$ & & & $\begin{array}{l}\text { Colonization rates of invertebrates after flooding events in four streams; Willow Creek (Tooele County), } \\
\text { Farmington Creek (Davis County), City and Mill Creeks (Salt Lake County) }\end{array}$ \\
\hline 67 & Mou-Sheng and Rushforth, 1977 & 4 & & & $\mathrm{x}$ & & Survey of algal flora of Brigham Young University campus \\
\hline 68 & Nebeker, 1966 & all & & $\mathrm{x}$ & & & Taxonomy and range of family Capniidae (Plecoptera); Western United States \\
\hline 69 & Needham and Christenson, 1927 & 1 & & $\mathrm{x}$ & & & Survey of invertebrates that are trout food; Logan River and nearby areas \\
\hline 70 & Newell and Minshall, 1976 & 1 & & $\mathrm{x}$ & & & Annotated checklist of Plecoptera; southeast Idaho \\
\hline 71 & Newell and Minshall, 1977 & 1 & & $\mathrm{x}$ & & & Annotated checklist of Trichoptera; southeast Idaho \\
\hline 72 & Norrington, 1925 & all & & & $\mathrm{x}$ & & Checklist of algae in lakes and streams; Wasatch and Uinta Mountains \\
\hline 73 & Oberndorfer and others, 1984 & 4 & & $\mathrm{x}$ & & & Leaf litter breakdown by invertebrate communities; North Fork Provo River \\
\hline 74 & Osborn, 1981 & 1 & & $\mathrm{x}$ & $\mathrm{x}$ & & $\begin{array}{l}\text { Invertebrate populations, chlorophyll, and leaf processing rates in relation to alkalinity; sites near } \\
\text { Logan, Utah, and near Yellowstone Park }\end{array}$ \\
\hline
\end{tabular}


Table 2. Selected investigations of the populations and interactions of fish, macroinvertebrates, and algae in the Great Salt Lake Basins study unit-Continued

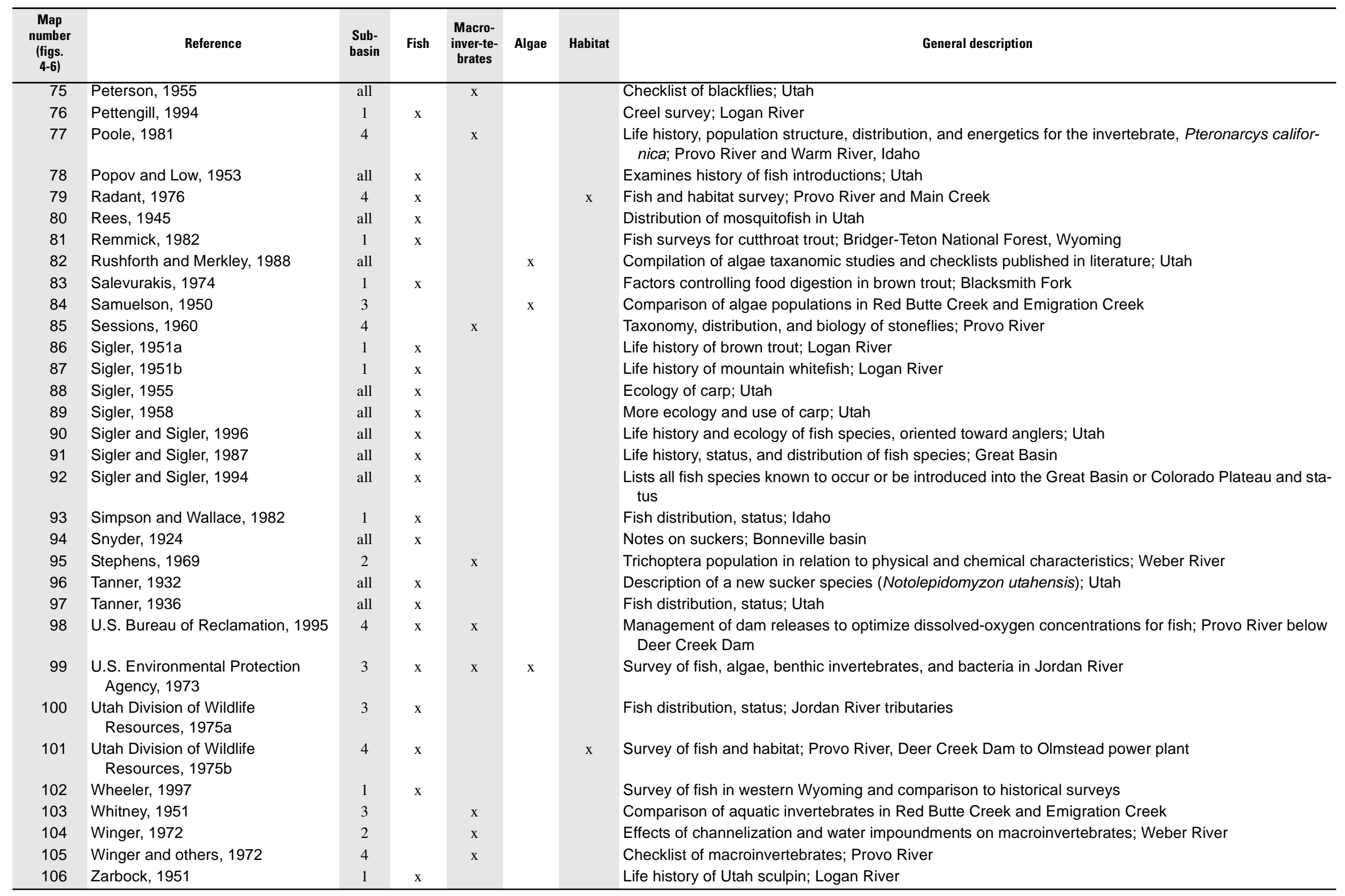




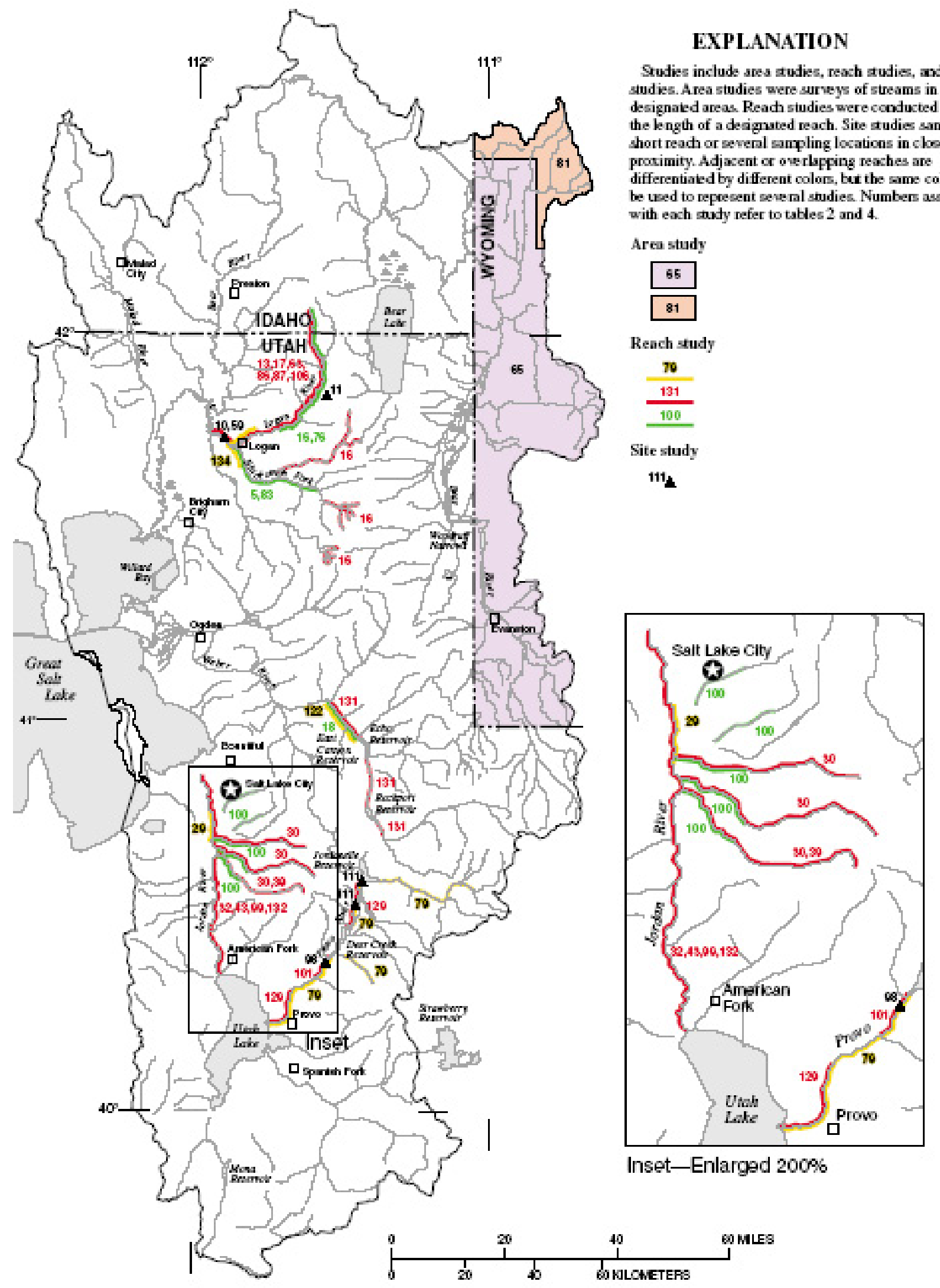

Figure 4. Location of studies of fish populations or surveys in the Great Salt Lake Basins study unit. 


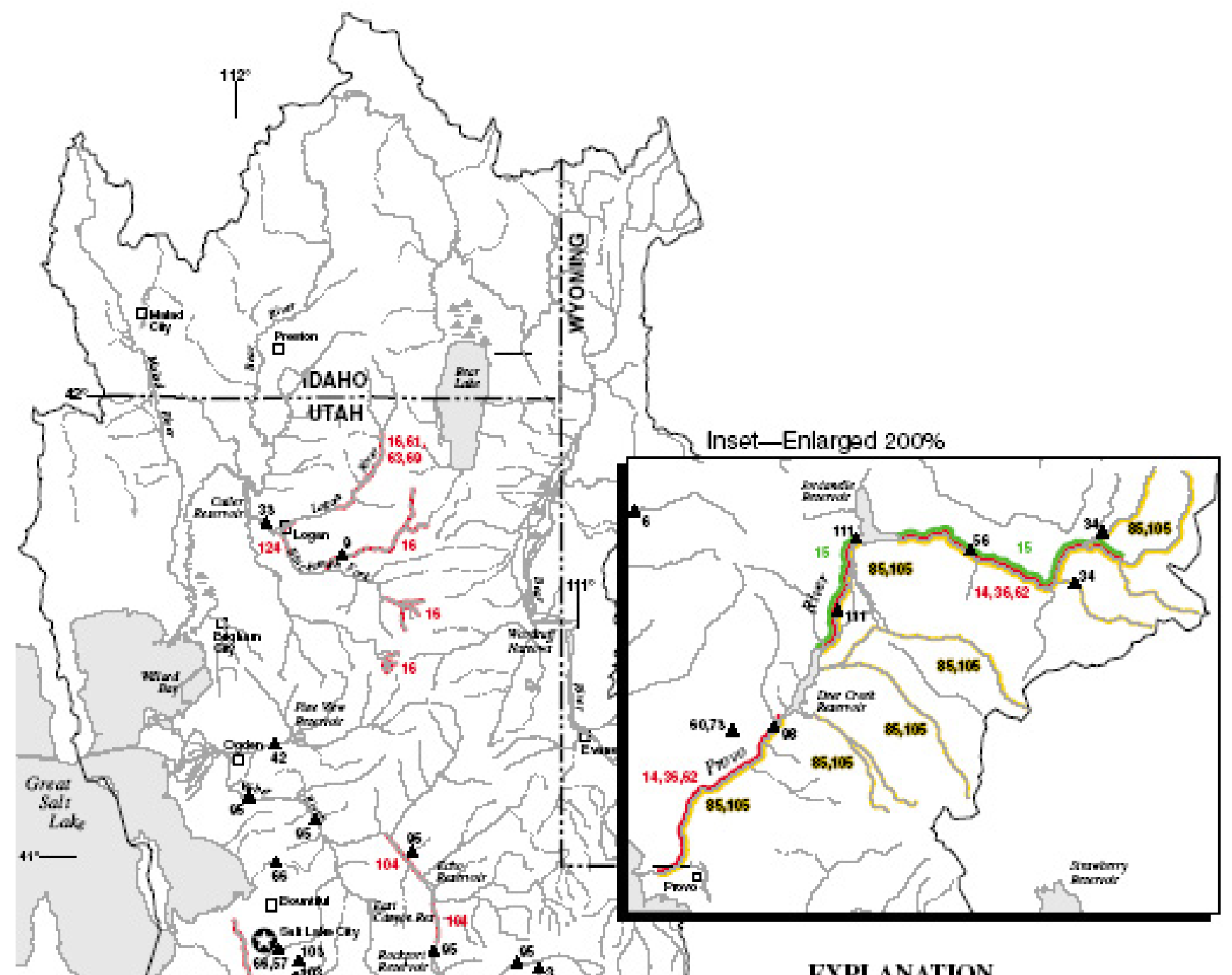

EXPLANATION

Studies include reach studies and ate sudies. Reach studies were conducted along the length of a designated reach. Site studies sampled a short reach or several sampling locations in cloee proximity. Adjacen or overlapping reaches are diffe rentiated by different colors, but the same color may be ured to represent several studies. Numbers associated with each sudy refer to tsbles 2 and 4.

Reach study

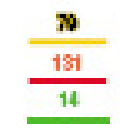

Site study

34 . OOMLES

Figure 5. Location of studies of macroinvertebrate populations or surveys in the Great Salt Lake Basins study unit, excluding water-quality monitoring sites. 


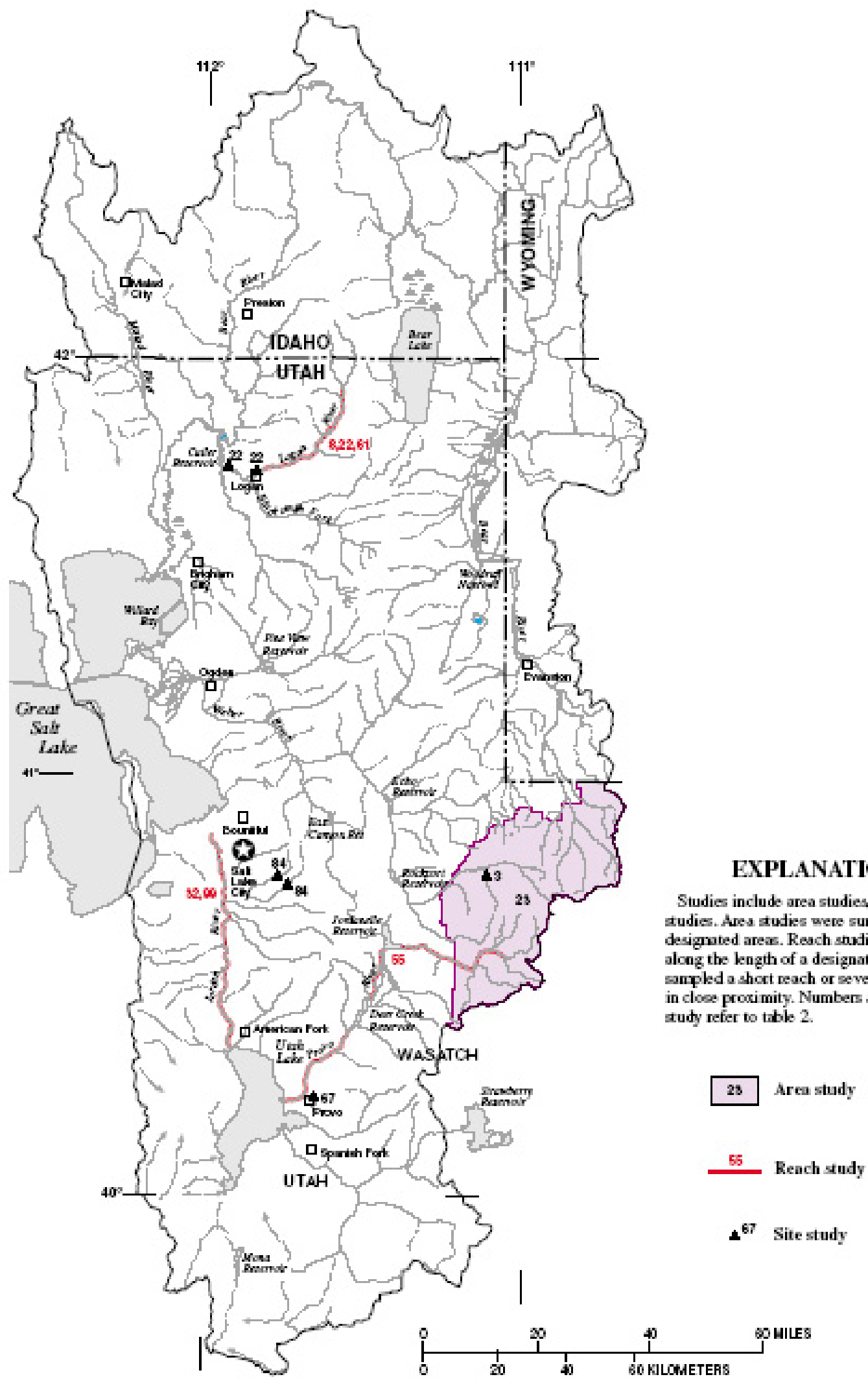

Figure 6. Location of studies of algal populations in the Great Salt Lake Basins study unit. 
community metrics to assess water quality. The stoneflies (Plecoptera) have been the subject of a number of surveys. Gaufin and others (1966) published a list with the taxonomy of stoneflies of Utah, and Nebeker (1966) published a dissertation on the ecology and taxonomy of the family Capniidae (Plecoptera) in the Western United States.

A number of studies on the ecology of macroinvertebrate communities have been conducted on streams located in the Great Salt Lake Basins study unit. For example, Behmer and Hawkins (1986) found that for most invertebrates, abundance and mean biomass are greater at sunny sites than shaded sites. Harvey studied the effects of predation on benthic macroinvertebrates, from trout (Harvey, 1993) and from a bird, the American dipper (Harvey and Marti, 1993). A number of studies examined the relations between invertebrates and physical and chemical characteristics of streams (Lium, 1969; Stephens, 1969; Alstad, 1978). Samuelson (1950) and Whitney (1951) compared the aquatic populations in Red Butte Creek, a NAWQA reference site, and Emigration Creek, a neighboring canyon with residential development. Both authors found that the macroinvertebrate and algal populations were more impaired in Emigration Creek and suggested that siltation was a major contributor to the impairment. Other studies examined the relations between macroinvertebrate communities and leaf-litter processing. Oberndorfer and others (1984) found that invertebrate shredders contributed substantially to leaf-litter breakdown in small streams, and that predation on shredders can have a substantial effect on detritus processing. This study was continued by McArthur and Barnes (1988), who further examined macroinvertebrate community dynamics in relation to leaf-litter processing. Osborn (1981) found that streams with higher alkalinity also had higher productions of aquatic invertebrates, higher standing crops of attached algae and faster processing of alder leaves.

Algal communities in the GSLB study unit generally are less studied than fish and macroinvertebrates. Norrington (1925) published the first comprehensive algal survey of sites within the study unit with his dissertation on the phycology of streams in the Wasatch and Uinta Mountains. Lawson and Rushforth (1975) also published an extensive account of diatoms in the Provo River, which emphasized taxonomic identification. More recently, Rushforth and Merkley (1988) published a comprehensive list of species and a literature review of algal taxonomy and surveys in Utah. A summary of these and other studies conducted on aquatic organisms and habitat is provided in table 2.

\section{Species of Special Concern}

Four fish and one amphibian species are of special concern in the GSLB study unit. The June sucker is listed as Endangered with Critical Habitat (U.S. Fish and Wildlife Service, 1986), and Conservation agreements and strategies exist for the Bonneville cutthroat trout (Utah Division of Wildlife Resources, 1996; Remmick and others, 1994; Scully, 1994; U.S. Forest Service, 1994), least chub (Perkins and others, 1997), and the spotted frog (U.S. Fish and Wildlife Service, 1998). The Conservation agreements implement strategies to maintain and increase the population of the species without listing them as Threatened or Endangered. In addition, the leatherside chub is considered rare and its population is being studied by the Utah Division of Wildlife Resources, but no management plan is currently in place for this species.

Many studies have been done to address life history, status, and distribution issues of each of these species (table 3 ). The cutthroat trout is the most visible and well studied of these species, probably because it is of interest to anglers. The Bonneville cutthroat trout is a subspecies of inland cutthroat trout, of which the Yellowstone, West Slope, Colorado River, and Rio Grande also are subspecies. Within the Bonneville subspecies, several differentiated groups exist. Two of these occur in the study unit: the Bear River form and the main Bonneville basin form. The Bonneville cutthroat trout interbreeds readily with Yellowstone cutthroat and rainbow trout. The introduction of Yellowstone cutthroat and rainbow trout species into Utah's rivers and lakes, in combination with habitat degradation, has led to the decline of the cutthroat species (Duff, 1996). The taxonomy of the inland cutthroat trout subspecies is complex and currently being assessed using genetic techniques (Shiozawa and Evans, 1995) in addition to more traditional, morphological techniques (Behnke and Proebstel, 1994). Duff (1996) provides an excellent discussion of the history, forms, and status of the Bonneville cutthroat trout. 
Tabỉe 3. Selected investigations of aquatic species of speciai concern in the Great Şait Lake Basins study unit

\begin{tabular}{|c|c|}
\hline Reference & General description \\
\hline \multicolumn{2}{|r|}{ Cutthroat trout studies } \\
\hline Behnke, 1976 & Status of Bonneville cutthroat trout \\
\hline Behnke, 1979 & Biology, taxonomy, distribution of western native trout \\
\hline Behnke, 1980 & Purity evaluation of Bear River cutthroat trout based on morphology; Carter and Mill Creeks \\
\hline Behnke, 1988 & Phylogeny and classification of all cutthroat trout species \\
\hline Behnke, 1992 & Biology, taxonomy, distribution of western native trout \\
\hline Behnke and Proebstel, 1994 & $\begin{array}{l}\text { Morphological analysis to determine subspecies of cutthroat trout in the Bonneville basin in } \\
\text { Idaho }\end{array}$ \\
\hline Bernard and Israelsen, 1982 & Migration of cutthroat trout between and within the Logan River and Spawn Creek \\
\hline Binns, 1977 & Status and distribution of Bonneville cutthroat trout in Wyoming \\
\hline Binns, 1981 & Status and distribution of Bonneville cutthroat trout in Wyoming \\
\hline Binns and Remmick, 1994 & Response of trout and their habitat to drainage-wide habitat management; Huff Creek \\
\hline Cope, 1955 & Reasons for decline of the cutthroat trout \\
\hline Cowley, 1994 & Survey of forest streams for cutthroat trout and other species of fish \\
\hline Duff, 1988 & Current status and management \\
\hline Duff, 1996 & Current status and management implications \\
\hline Floener, 1950 & Life history of cutthroat trout in Logan River \\
\hline Griffith, 1988 & Competition between cutthroat trout and other salmonids \\
\hline Hickman, 1977 & Status of Bonneville cutthroat trout \\
\hline Hickman, 1978 & Study of Bonneville cutthroat trout \\
\hline Holden and others, 1974 & Notes on all threatened fish in Utah \\
\hline Martin and others, 1985 & Electrophoresis study \\
\hline Martin and Shiozawa, 1982 & Electrophoresis study \\
\hline May and others, 1978 & Distribution, systematics and biology \\
\hline Nielson and Lentsch, 1988 & Bear Lake cutthroat trout status and management \\
\hline Nielson and Tolentino, 1996 & Bear Lake cutthroat trout enhancement program progress report, 1990-94 \\
\hline Remmick, 1982 & Survey of populations on Bridger-Teton National Forest, Wyoming \\
\hline Remmick and others, 1994 & Five year management plan, Wyoming \\
\hline Schmidt and others, 1995 & Management plan, Utah \\
\hline Scully, 1993 & Status of Bonneville cutthroat trout in Idaho \\
\hline Scully, 1994 & Habitat conservation assessment and strategy, Idaho \\
\hline Shiozawa and Evans, 1995 & Genetic status (mitochondrial DNA analysis) \\
\hline Shiozawa and others, 1993 & Relations between cutthroat trout populations in 10 Bonneville and Colorado River drainages \\
\hline Trotter and Bisson, 1988 & Documents early observations of cutthroat trout \\
\hline U.S. Forest Service, 1994 & Conservation agreement for the Thomas Fork, Wyoming/Idaho \\
\hline $\begin{array}{l}\text { Utah Division of Wildlife Resources, } \\
1996\end{array}$ & Draft conservation agreement and strategy of Bonneville cutthroat trout in Utah \\
\hline Wullschleger and Pettengill, 1993 & Logan River cutthroat trout spawning study \\
\hline Wullschleger and Pettengill, 1994 & Logan River fish population surveys \\
\hline Young, 1995 & Distribution, status of inland cutthroat trout species \\
\hline
\end{tabular}


Table 3. Selected investigations of aquatic species of special concern in the Great Salt Lake Basins study unit-Continued

Reference General description

Crowl and others, 1995a

Crowl and others, 1995b

Eyring Research Institute, 1982

Gutermuth and others, 1993

Lamarra, 1982

Modde and Muirhead, 1990

Modde and Muirhead, 1994

Olsen and others, 1996

Radant, 1986

Radant and others, 1987

Radant and Shirley, 1987

Shirley, 1983

U.S. Fish and Wildlife Service, 1986

U.S. Fish and Wildlife Service, 1995a

Crawford, 1979

Hickman, 1989

Lamarra, 1982

Perkins and others, 1997

U.S. Fish and Wildlife Service, 1995b

Johnson and others, 1995

Wheeler, 1997

Wilson and others, 1998

Bissonette and Larsen, 1991

Hovingh, 1987

Perkins and Lentsch, 1998

Ross and others, 1993

Ross and Peterson, 1998

Shirley, 1993

Toline and Seitz, 1999

U.S. Fish and Wildlife Service, 1998
Trophic interactions of June sucker, gizzard shad, and white bass

Various June sucker studies

Water quality, hydrology, and aquatic biology assessment of Utah Lake

Reproductive biology of the June sucker

Status of June sucker (and webug sucker, now same species) and least chub

Emergence patterns and feeding of June sucker

Spawning and larval emergence of June sucker

Analysis of factors affecting June sucker spawning habitat

History, ecology, and management of June sucker

Instream flow analysis for June sucker; Provo River

Miscellaneous June sucker investigations

Spawning and larval development of June sucker

Decision to list June sucker as endangered with critical habitat

June sucker recovery plan

\section{Least chub studies}

Reproduction of the least chub

Status of least chub in Intermountain West

Status of June sucker and least chub

Conservation agreement and strategy

Proposal to list species as endangered

\section{Leatherside chub studies}

Life history

Distribution of fish in western Wyoming and changes in distribution

Distribution and abundance in Heber Valley, Provo River

\section{Spotted frog studies}

Bibliography of spotted frog literature

Status of spotted frog in Bonneville basin

Conservation strategy

Survey for frogs along Wasatch Front, 1991-92

Habitat requirements and restoration recommendations along Provo River

Translocation of frog egg masses from Jordanelle Reservoir site

Genetic variations of Utah spotted frog populations

Conservation agreement 
The June sucker is the only aquatic species designated as endangered in the study unit. Its range is limited to Utah Lake and the lower Provo River, where it spawns. The lower Provo River is heavily used for water supply, and maintenance of adequate instream flow for successful spawning has been a significant issue for survival of the June sucker. Spawning and instream flow in the Provo River have been examined by Radant and Sakaguchi (1981), Modde and Muirhead (1994), Shirley (1983), Gutermuth and others (1993), and Olsen and others (1996). The dynamics of the population in Utah Lake have been and continue to be examined (Crowl and others, 1995b; Eyring Research Institute, 1982; Radant and Shirley, 1987).

The least chub is a member of the minnow family that is endemic to the Bonneville basin. Historically, it was widely distributed in streams, lakes, springs, and wetlands but now is reduced almost entirely to the Snake Valley in western Utah. One small population has been located in Juab County, south of Utah Lake, the only population occurring in the study unit. Habitat loss and degradation caused by urbanization and livestock trampling and grazing have been cited as the major reasons for the species' decline. The species was proposed as Endangered with Critical Habitat by the U.S. Fish and Wildlife Service in 1995 (1995b).

The leatherside chub also is a Utah species of special concern and is Federally listed as a candidate species, although no interagency conservation agreement currently exists for this species. Historically, this species occurred in the eastern and southern drainages of the Bonneville basin, including the Utah Lake, Great Salt Lake, and Sevier River drainages. It also was found in the upper Snake and Bear River drainages in Wyoming and the Little Wood River in Idaho. Its range has been greatly reduced, but it is still found in the Sevier and Provo River drainages in the Bonneville basin, as well as some areas in the Colorado River Basin (Holden and others, 1996).

The spotted frog in Utah is a highly aquatic amphibian that lives in springs in the Wasatch Front and West Desert mountains. Utah and Nevada are at the southern extent of the range of this species, which extends north to the Pacific Northwest and Alaska. Populations in Utah differ from those in the Pacific Northwest and have been proposed as a separate species, but no standardized designation has been accepted (U.S. Fish and Wildlife Service, 1998). Populations of the spotted frog in Utah have been fragmented historically, but are now threatened by urban and water development projects and the introduction of exotic species. The species was proposed to be listed as Threatened in 1989 under the Endangered Species Act but the designation was precluded by higher priorities. Bissonette and Larsen (1991) provide an annotated bibliography of spotted frog literature, and the Conservation Strategy (Perkins and Lentsch, 1998) provides background information on the life history, status, and management of the species.

\section{Aquatic Habitat and Riparian Wetlands}

Studies of aquatic communities often contain limited information about stream habitat but studies that focus solely on the characterization of stream habitat are not as common. Many of the studies included in this report examine the effects of channel or flow changes on aquatic communities (table 4, fig. 7). Dunstan (1951) found that invertebrate communities were adversely affected by dredging in the Provo River where the channel was enlarged to accommodate increased flows. However, Winger (1972) and Reger (1980) found that macroinvertebrate communities, although initially depleted, recovered fairly quickly following habitat alterations, depending on the severity of the alteration and time required for the substrate to stabilize. Winger also found that the distribution of species differed upstream and downstream from impoundments and speculated that the impoundments had more effect on the distribution of species than habitat alterations.

Effects of channel alterations on fish were examined by Dunstan (1951), Wilson (1984), and Wydoski and Helm (1980). All three studies agree that fish, especially trout populations, were adversely affected by dredging, mostly because of a loss of pool habitat and instream cover. Peters (1974) found that fish communities in a channelized section of the Weber River did return to prechannelized conditions when artificial habitat structures were put in place. A series of reports examined microhabitat requirements of brown trout and their response to channel alterations (Gosse and Helm, 1979; Gosse, 1981; Helm, 1982). Chrostowski (1972) and the Utah Division of Wildlife Resources (1975b) examined instream flow requirements of game fish for management of the Provo River system. 
Table 4. Selected investigations of aquatic habitat and riparian wetlands in the Great Salt Lake Basins study unit

[Subbasins: 1, Bear River Basin; 2, Weber River Basin; 3, Jordan River Basin; 4, Provo River/Utah Lake Basin]

\begin{tabular}{|c|c|c|c|c|c|c|c|c|c|}
\hline $\begin{array}{c}\text { Map } \\
\text { number } \\
\text { (fig. 7) }\end{array}$ & Reference & $\begin{array}{c}\text { Sub- } \\
\text { basin }\end{array}$ & Wetland & $\begin{array}{l}\text { Channel } \\
\text { stability }\end{array}$ & Habitat & $\begin{array}{l}\text { Restora- } \\
\text { tion }\end{array}$ & Fish & $\begin{array}{c}\text { Algae or } \\
\text { inverte- } \\
\text { brates }\end{array}$ & General description \\
\hline 107 & Bailey and Larson, 1968 & 4 & & $\mathrm{x}$ & & & & & Channel deterioration and stability problems associated with the Duchesne tunnel \\
\hline 108 & Binns and Eiserman, 1979 & 1 & & & $\mathrm{x}$ & & $\mathrm{x}$ & & Quantification of trout habitat; Wyoming \\
\hline 109 & CH2MHill, 1992 & 3 & & $\mathrm{x}$ & & & & & Channel stability analysis and management/development plan \\
\hline 110 & Chrostowski, 1972 & 4 & & $\mathrm{x}$ & $\mathrm{x}$ & & $\mathrm{x}$ & & $\begin{array}{l}\text { Analysis of minimum and maximum flows possible without damaging fishery and } \\
\text { habitat; Diamond Fork and Sixth Water (streams affected by water diversions) }\end{array}$ \\
\hline 111 & Dunstan, 1951 & 4 & & & $\mathrm{x}$ & & $\mathrm{x}$ & $\mathrm{x}$ & $\begin{array}{l}\text { Effects of dredging to increase channel capacity on fish, invertebrates, and habitat; } \\
\text { Provo River above Deer Creek Reservoir }\end{array}$ \\
\hline 112 & Gosse, 1981 & 1 & & & $\mathrm{x}$ & & $\mathrm{x}$ & & $\begin{array}{l}\text { Microhabitat requirements of brown trout and response to channel alterations; } \\
\text { Logan River }\end{array}$ \\
\hline 113 & Gosse and Helm, 1979 & 4 & & & $\mathrm{x}$ & & $\mathrm{x}$ & & Effects of flow alterations on trout microhabitats; Provo River \\
\hline 114 & Halpin, 1987a & 3 & $\mathrm{x}$ & & & & & & Vegetation survey of wetlands along the Jordan River \\
\hline 115 & Halpin, 1987b & 3 & $\mathrm{x}$ & & & & & & Survey of birds, mammals, reptiles, and amphibians using wetlands; Jordan River \\
\hline 116 & Helm, 1982 & 1 & & & $\mathrm{x}$ & & $\mathrm{x}$ & & $\begin{array}{l}\text { Method to predict distribution of brown trout based on microhabitat; Blacksmith } \\
\text { Fork }\end{array}$ \\
\hline 117 & Jensen, 1989 & 3 & $\mathrm{x}$ & & & & & & Functional assessment and prioritization of wetlands; Jordan River \\
\hline 118 & Jensen, 1993 & 3 & $\mathrm{x}$ & & & & & & $\begin{array}{l}\text { Ecological and functional assessment of Albion basin wetlands; Little Cottonwood } \\
\text { Creek }\end{array}$ \\
\hline 119 & Jensen, 1995 & 3 & & $\mathrm{x}$ & & & & & Management plan for hydrologic modifications; Jordan River \\
\hline 120 & Nabrotzky, 1987 & 3 & $\mathrm{x}$ & & & & & $\mathrm{x}$ & Survey of macroinvertebrates associated with wetlands; Jordan River \\
\hline 121 & Olsen and others, 1996 & 4 & & & $\mathrm{x}$ & & & & $\begin{array}{l}\text { Analysis of flow, habitat, and algae cover for spawning grounds; lower Provo } \\
\text { River }\end{array}$ \\
\hline 122 & Peters, 1974 & 2 & & & $\mathrm{x}$ & $\mathrm{x}$ & $\mathrm{x}$ & & Success of fish habitat restoration in channelized section; Weber River \\
\hline 123 & Radant, 1976 & 4 & & & $\mathrm{x}$ & & $\mathrm{x}$ & & Survey of fish and their habitat; Provo River, Main Creek \\
\hline 124 & Reger, 1980 & 1 & & & $\mathrm{x}$ & & & $\mathrm{x}$ & $\begin{array}{l}\text { Effect of habitat alterations on macroinvertebrates; Logan River, Grand Ronde } \\
\text { River, Oregon }\end{array}$ \\
\hline 125 & Shaw, 1986 & all & & & $\mathrm{x}$ & & $\mathrm{x}$ & & Habitat requirements for cutthroat trout; Wasatch National Forest streams \\
\hline 126 & Smith and Maderak, 1993 & 1 & & $\mathrm{x}$ & & & & & Channel stabilization of Bear River near Evanston, Wyoming \\
\hline 127 & Stephens and Gerner, 1996 & all & $\mathrm{x}$ & & & & & & Utah's wetland resources, types of wetlands, conservation strategies \\
\hline 128 & $\begin{array}{l}\text { Utah Department of Environmental } \\
\text { Quality, } 1996\end{array}$ & $1,2,3$ & $\mathrm{x}$ & & $\mathrm{x}$ & & & & $\begin{array}{l}\text { Analysis of water quality and wetland resources and their designated uses; lower } \\
\text { Bear River, Weber River, and Jordan River Basins }\end{array}$ \\
\hline 129 & Utah Division of Wildlife Resources, 1957 & 4 & & & $\mathrm{x}$ & & $\mathrm{x}$ & & Effects of channelization on fish and habitat; Provo River \\
\hline 130 & West, 1984 & 3 & $\mathrm{x}$ & & & & & & Survey of wetlands in Salt Lake County \\
\hline 131 & Wilson, 1984 & 2 & & & $\mathrm{x}$ & & $\mathrm{x}$ & & Effects on fish populations from loss of habitat through dredging; Weber River \\
\hline 132 & Wilson, 1987 & 3 & $\mathrm{x}$ & & $\mathrm{x}$ & $\mathrm{x}$ & $\mathrm{x}$ & & Suggestions for restoring fish populations due to habitat degradation; Jordan River \\
\hline 133 & Winger, 1972 & 2 & & & $\mathrm{x}$ & & & $\mathrm{x}$ & Effects of channelization and impoundments on invertebrates; Weber River \\
\hline 134 & Wydoski and Helm, 1980 & 1 & & & $\mathrm{x}$ & & $\mathrm{x}$ & & $\begin{array}{l}\text { Effects of channel alterations on brown trout and mountain whitefish; Logan River } \\
\text { and Blacksmith Fork }\end{array}$ \\
\hline
\end{tabular}




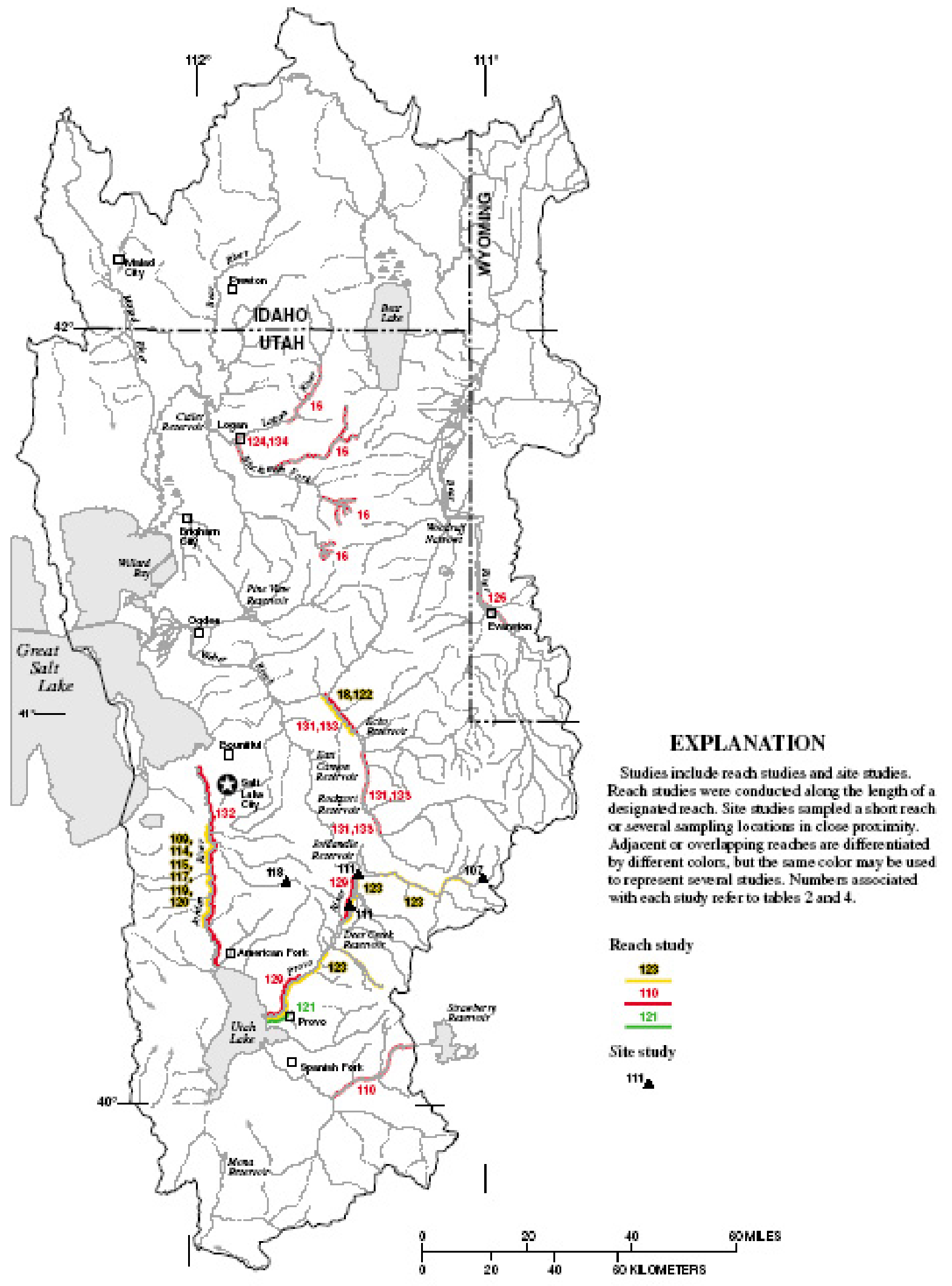

Figure 7. Location of studies of aquatic habitat in the Great Salt Lake Basins study unit. 
Wetlands in the study unit have not been studied extensively. An Advance Identification Study of the Jordan River wetland system was conducted in the late 1980s and included surveys of vegetation (Halpin, 1987a), wildlife resources (Halpin, 1987b), macroinvertebrates (Nabrotzky, 1987), fisheries (Wilson, 1987), and functional assessment (Jensen, 1989). Jensen also examined wetlands in the Albion basin of the Little Cottonwood Creek watershed (Jensen, 1993), and West (1984) conducted a survey of wetlands in Salt Lake County. Wetlands along Great Salt Lake are important habitat for migratory waterfowl, but studies in this regard are not included in this report because waterfowl is not a focus of the NAWQA program.

\section{Contaminants}

Early studies of contaminants in the GSLB study unit generally dealt only with water quality. Many of the studies that relate water quality to species diversity and abundance were done in the 1950s and 1960s as part of a program established by Dr. Arden Gaufin and other faculty members of the University of Utah.

Resource assessment and planning studies done within the Utah Lake-Jordan River Basin in the 1970s were funded by the U.S. Environmental Protection Agency as an outgrowth of the Clean Water Act.

As the human population grew and the level of water-borne contaminants increased, studies expanded to include bottom sediment and biota as accumulators of contaminants. With the exception of a few pioneering water-quality studies, the review and synopsis of studies of contaminants transported in water within the study unit is limited to bottom sediment and biological tissues. Additional studies are referenced that show generalized effects of pollutants on organism distribution (table 5, fig. 8). Studies are presented in reverse chronology by location, according to drainage basin.

\section{Utah Lake-Jordan River Basin}

A report that describes contaminant levels in stream-bottom sediment, fish, aquatic plants, and some waterfowl in the Spanish Fork-Nephi area that drains to Utah Lake or Mona Reservoir was completed by CH2M Hill (1995). Levels of environmental exposure and bioaccumulation of contaminants were associated with water quality for the area. Projected effects of the Central Utah Project Completion Act irrigation facilities on water-quality condition were then used to estimate the potential contaminant effects on the biota of the area. Concentrations of trace elements, organochlorine pesticides, and PCBs in bottom sediment and biota tissues were evaluated using effect-level criteria from the literature.

The ability of submersed aquatic plants to accumulate metal ions from bottom sediment was investigated by Lytle (1994). Sago pondweed in particular was found to concentrate high levels of manganese, zinc, and iron. Submersed aquatic plant species from the Provo River drainage, Bear River Migratory Bird Refuge, and Utah Lake-Provo Bay were significantly higher in heavy metals than aquatic species from remote wetlands. Heavy metal concentrations in submersed aquatic plants from the Great Basin were higher in wetlands affected by urban, industrial, and agricultural activities.

An extensive study of trace metal distribution in four Utah lakes was done to determine if sources were anthropogenic (mining) or atmospheric in origin (Kada and others, 1994). Bottom-sediment cores were collected from Panguitch Lake in southern Utah, Mirror Lake in the Duchesne River drainage, and in two reservoirs in the GSLB study unit: (1) Echo Reservoir in the Weber River drainage, and (2) Deer Creek Reservoir in the Provo River drainage. Cores were age dated using cesium 137 and lead 210. Panguitch Lake and Mirror Lake had very low concentrations of copper, cadmium, lead, thallium, tin, and zinc that were believed to represent background levels or input from atmospheric sources. Echo and Deer Creek Reservoirs had higher concentrations of the metals and mining was believed to be the source in both basins. Echo Reservoir profiles showed peak inputs of the metals during 1950-51 that are believed to be associated with the Park City mining complex upstream. Deer Creek Reservoir had concentrations of copper, lead, thallium, and zinc that were orders of magnitude greater than could occur from atmospheric deposition. Mining was believed to be the source of the contaminants because it was the dominant anthropogenic activity in the Deer Creek basin.

Geochemical and lead isotope data were collected at nine sites along the Jordan River from Jordan 
₹ Table 5. Selected investigations on the presence and effects of contaminants in sediments or fish tissue in the Great Salt Lake Basins study unit

\begin{tabular}{|c|c|c|c|c|c|c|}
\hline $\begin{array}{c}\text { Map } \\
\text { number } \\
\text { (fig. 8) }\end{array}$ & Reference & $\begin{array}{l}\text { Water } \\
\text { quality }\end{array}$ & $\begin{array}{c}\text { Organic } \\
\text { conta- } \\
\text { minant }\end{array}$ & $\begin{array}{c}\text { Inorganic } \\
\text { conta- } \\
\text { minant }\end{array}$ & $\begin{array}{c}\text { Aquatic } \\
\text { com- } \\
\text { munity }\end{array}$ & General description \\
\hline 1 & Adams and others, 1975 & $\mathrm{x}$ & & & $\mathrm{x}$ & Effects of natural organic compounds on biota; Hyrum Reservoir \\
\hline 2 & Anderson, 1963 & & & & $\mathrm{x}$ & Effects of geology on productivity; Smith-Morehouse Creek \\
\hline 3 & CH2M Hill, 1995 & & $\mathrm{x}$ & $\mathrm{x}$ & $\mathrm{x}$ & Description of contaminants in sediments, fish, macrophytes, and waterfowl; Spanish Fork Canyon, Nephi \\
\hline 4 & Carter, 1971 & $\mathrm{x}$ & & & $\mathrm{x}$ & Effects of new causeway on biota of Farmington Bay \\
\hline 5 & Eldredge, 1967 & & $\mathrm{x}$ & & $\mathrm{x}$ & DDT and isomers of fish from Utah Lake \\
\hline 6 & Environmental Dynamics, 1975 & & $\mathrm{x}$ & & $\mathrm{x}$ & $\begin{array}{l}\text { Baseline conditions of fish, invertebrates, and algae in Jordan River are established, some information on con- } \\
\text { taminants }\end{array}$ \\
\hline 7 & Gaufin, 1957 & $\mathrm{x}$ & & & & Water quality of Weber, Jordan, Provo, and Price Rivers \\
\hline 8 & Henderson and others, 1972 & & & $\mathrm{x}$ & $\mathrm{x}$ & National Pesticide Monitoring Program results, mercury in fish; Utah Lake, Bear River at Preston, Idaho \\
\hline 9 & Hinshaw, 1967 & $\mathrm{x}$ & & & $\mathrm{x}$ & Compared water quality and aquatic insect communities in Jordan River in 1958 and 1965 \\
\hline 10 & Hydroscience, 1977 & $\mathrm{x}$ & & & & Water quality of major Jordan River tributaires in valley reaches \\
\hline 11 & Jorgenson, 1961 & $\mathrm{x}$ & & & $\mathrm{x}$ & Relation between basic water-quality characteristics and macroinvertebrate community; upper Weber River \\
\hline 12 & Kada and others, 1994 & & & $\mathrm{x}$ & & Trace elements in sediment cores from lakes and reservoirs; Echo Reservoir, Deer Creek Reservoir, and others \\
\hline 13 & Lemke, 1954 & $\mathrm{x}$ & & & $\mathrm{x}$ & Examined loading to stream from organic material; Mill Creek \\
\hline 14 & Lindvall and Low, 1979 & & $\mathrm{x}$ & & $\mathrm{x}$ & Organic contaminants in Grebes; Bear River Migratory Bird Refuge \\
\hline 15 & Lytle, 1994 & & & $\mathrm{x}$ & $\mathrm{x}$ & Trace-metal concentrations in macrophytes; Provo River, Utah Lake, Bear River Bird Refuge \\
\hline 16 & Qi and Heckmann, 1995 & & & & $\mathrm{x}$ & Microscopic examination of parasite on Mottled sculpin; Provo River \\
\hline 17 & Quinn, 1958 & $\mathrm{x}$ & & & $\mathrm{x}$ & Effects of sugar beet wastes upon the periphyton of the Jordan River \\
\hline 18 & Schmitt and Brumbaugh, 1990 & & & $\mathrm{x}$ & $\mathrm{x}$ & National contaminant biomonitoring program, trace metals in fish; Bear River at Brigham City, Utah Lake \\
\hline 19 & Schmitt and others, 1990 & & $\mathrm{x}$ & & $\mathrm{x}$ & National contaminant biomonitoring program, organochlorine in fish; Bear River at Brigham City, Utah Lake \\
\hline 20 & Schmitt and others, 1983 & & $\mathrm{x}$ & & $\mathrm{x}$ & National Pesticide Monitoring Program, organochlorine in fish; Bear River at Brigham City, Utah Lake \\
\hline 21 & Schmitt and others, 1981 & & $\mathrm{x}$ & & $\mathrm{x}$ & National Pesticide Monitoring Program, organochlorine in fish; Bear River at Preston, Idaho, Utah Lake \\
\hline 22 & Smith, 1959 & $\mathrm{x}$ & & & $\mathrm{x}$ & Water quality and aquatic communities in Weber River and Silver Creek \\
\hline 23 & Squires, 1977 & $\mathrm{x}$ & & & $\mathrm{x}$ & Algal response to a thermal effluent; Provo River \\
\hline 24 & Stephens, 1984 & & $\mathrm{x}$ & $\mathrm{x}$ & & Toxic substances in water and sediment; Jordan River, Big and Little Cottonwood and Mill Creeks \\
\hline 25 & Thompson, 1983 & $\mathrm{x}$ & $\mathrm{x}$ & & & Water-quality assessment, sediments; Weber River Basin and sloughs \\
\hline 26 & Thompson, 1984 & & $\mathrm{x}$ & $\mathrm{x}$ & & Toxic substances in water and sediment; Jordan River, Big and Little Cottonwood and Mill Creeks \\
\hline 27 & $\begin{array}{l}\text { U.S. Environmental Protection } \\
\text { Agency, } 1973\end{array}$ & $\mathrm{x}$ & & & $\mathrm{x}$ & Bacteriological study of Jordan River and Emigration Creek \\
\hline 28 & $\begin{array}{l}\text { Utah Division of Wildlife Resources, } \\
1975 \mathrm{~b}\end{array}$ & $\mathrm{x}$ & & & $\mathrm{x}$ & Survey of fish and habitat; Provo River, Deer Creek Dam to Olmstead power plant \\
\hline 29 & Waddell and Coyner, 1990 & & $\mathrm{x}$ & $\mathrm{x}$ & & Evaluation of contaminants in water and sediments; Utah Lake wetlands \\
\hline 30 & Waddell and others, 1990 & & $\mathrm{x}$ & $\mathrm{x}$ & & Evaluation of contaminants in sediments and water; Bear River Migratory Bird Refuge \\
\hline 31 & Waddell and Stephenson, 1992 & & & $\mathrm{x}$ & $\mathrm{x}$ & Trace elements in biota; Utah Lake, Provo Bay \\
\hline 32 & Way, 1980 & $\mathrm{x}$ & & & $\mathrm{x}$ & Examines fishery potential of Jordan River based on differing wastewater treatment alternatives \\
\hline
\end{tabular}


Narrows to Cudahy Lane in Davis County to assess heavy-metal contamination of the bottom sediment (S.E. Church, S.A. Wilson, R.B. Vaughn, and P.H. Briggs, U.S. Geological Survey, written commun., 1993). Sediment and soils from the Bingham pit area and Sharon Steel Mill and smelter sites showed a high concentration of labile metals, particularly copper, lead, and zinc. Labile metals are those that are sorbed to clays or other sediments and are thought to be more readily bioavailable than metals in silicate or sulfide minerals. Sampling of these stream sites clearly identified them as substantial point sources of heavy metals to the Jordan River.

A survey of contaminants in water and bottom sediment completed in 1988 (Waddell and Coyner, 1990) indicated the presence of high concentrations of some trace elements in Spring Creek, a tributary to Utah Lake. In 1990, samples of waterbird eggs and livers, and aquatic vegetation were collected at the five sites sampled in 1988 to determine if elevated concentrations of trace elements were present in the biota (Waddell and Stephenson, 1992). The concentration of mercury was elevated in one bird egg from Benjamin Slough and selenium in most waterbird eggs was present at concentrations that exceeded levels of concern. Lead concentrations in vegetation at Provo Bay (mouth of Spring Creek) were measured at levels hazardous to wildlife.

Waddell and Coyner (1990) investigated the potential for contaminants in an area of Utah Lake proposed for a National Wildlife Refuge. Water and sediment from four tributaries discharging to Utah Lake and from the lake outlet to the Jordan River were sampled for selected inorganic elements and pesticides. Sediment from most sites did not contain elevated concentrations of contaminants. However, a sediment sample from Spring Creek had high concentrations of arsenic (9 $\mu \mathrm{g} / \mathrm{g})$, cadmium $(8 \mu \mathrm{g} / \mathrm{g})$, copper $(51 \mu \mathrm{g} / \mathrm{g})$, lead (500 $\mu \mathrm{g} / \mathrm{g})$, manganese $(550 \mu \mathrm{g} / \mathrm{g})$, and zinc $(1,600 \mu \mathrm{g} / \mathrm{g})$. Metabolites of dichloro-diphenyl-trichloro-ethane (DDT) were present at a concentration of $3.7 \mu \mathrm{g} / \mathrm{kg}$ at the same site.

Water-quality studies were done by the U.S. Geological Survey on the Jordan River between 1980 and 1982 to investigate specific problems involving dissolved oxygen, toxic substances, sanitary quality and turbidity. A summary of these individual studies is listed in Stephens (1984). Results of the contaminant part of the study are in Thompson (1984). Toxic substances in water and bottom sediments were investigated at five sites along the Jordan River (Jordan Narrows and downstream) and in inflows from three tributaries (Big and Little Cottonwood Creeks and Mill Creek). Water concentrations of ammonia, cadmium, copper, cyanide, iron, lead, mercury, and zinc were elevated, especially in storm water. Concentrations of metals in bottom sediment increased substantially at sites downstream of 5800 South Street compared with two sites upstream. Concentrations of arsenic, cadmium, and chromium were twice as high at downstream sites, copper and zinc were six times, and lead was eight times higher at downstream sites when compared to upstream sites.

Concentrations of metals in bottom sediment from the tributaries were similar to the downstream Jordan River sites. Nine of 18 organic constituents were detected in bottom sediment with PCBs most common. Concentrations of PCBs were highest at Jordan Narrows $(320 \mu \mathrm{g} / \mathrm{kg})$ and declined downstream. Chlorinated hydrocarbon pesticides were found at most sites, but with the exception of a 2,4-dinitrophenol (2,4-D) concentration of $320 \mu \mathrm{g} / \mathrm{kg}$ at the mouth of Big Cottonwood Creek, concentrations did not exceed $15 \mu \mathrm{g} / \mathrm{kg}$.

The effects of urbanization on the incidence of external and internal parasites of sculpin were reported by Qi and Heckmann (1995). Samples of 160 sculpin were collected from two sites on the Provo River: (1) within the Provo City municipal area, and (2) in a relatively pristine area near Jordanelle Reservoir. High numbers of two species of ciliated protozoa were found on the gills of sculpins from both areas. For one species of the protozoa Trichodina, the incidence of infestation was greater on fish from the Provo residential area during the spring. This infestation is believed to be caused by chemical and physical stressors resulting from urbanization of the area.

Several water-quality studies done in accordance with the Federal Water Pollution Control Act Amendments of 1972 (Public Law 92-500) are summarized by Environmental Dynamics (1975). In addition to baseline conditions of aquatic species, the report includes 


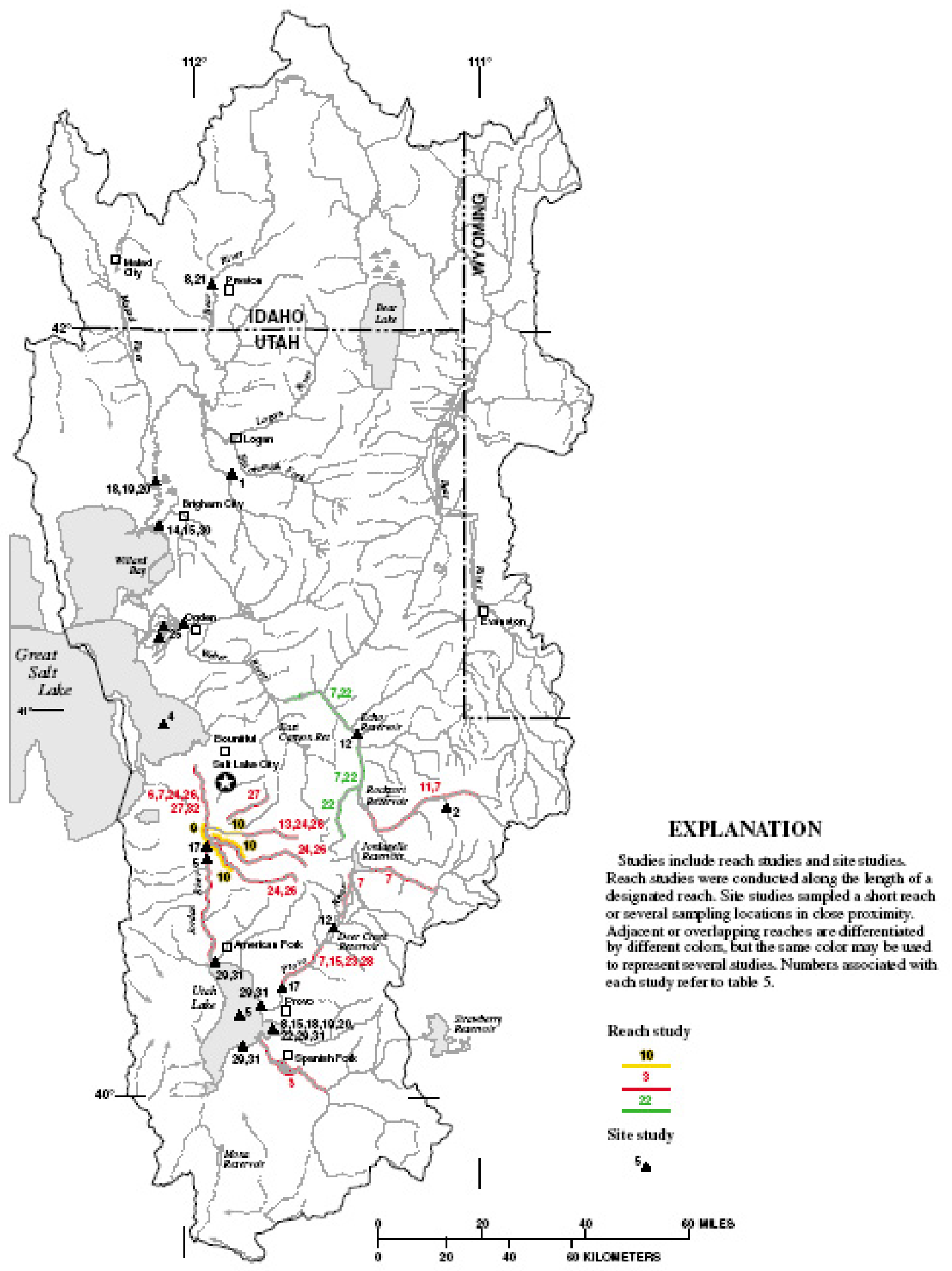

Figure 8. Location of studies of contaminants in sediments or fish tiseves in the Great Salt Lake Basins study unit. 
baseline information on organic contaminants and dissolved oxygen.

The need for specific treatment procedures for wastewater discharged to the Jordan River was addressed by Way (1980) as part of long-range planning for Salt Lake County. Instream "safe levels" of temperature, dissolved oxygen, chlorine, ammonia, and detergent are summarized for seven species of resident fish. Way concluded that the cold water and warm water fishery in upper and lower reaches of the river would not be constrained by poor water quality if denitrification and dechlorination were included as part of planned wastewater treatment. Habitat restoration also was believed to be necessary to obtain self-supporting populations. Way (1980) does not address pesticides, herbicides, and heavy metals that could have a substantial limiting effect on the fishery.

As part of water-resources management in Salt Lake County, Hydroscience, Inc. (1977) reported on water quality in the valley segments of five streams in the Wasatch Mountains. This report also investigated modeling of storm-water runoff for Big and Little Cottonwood Creeks. Much of the information presented on local fisheries was gathered from a limited study by the Utah Division of Wildlife Resources in 1975 (Utah Division of Wildlife Resources, 1975a). In all five of the Wasatch tributaries, fish populations were either precluded by water-quality problems or were limited by them. Future sedimentation was predicted to be a problem in several of the streams.

The effects of a hydroelectric power plant on periphyton in the Provo River were investigated by Squires (1977). During spring and summer, species diversity of reaches affected by heated effluent and unaffected control areas was similar. During fall and winter, species diversity increased in control areas, but not in effluentaffected areas. The composition of species in effluent and control areas differed at all times.

The fishery of the Provo River was described in a study done by the Utah Division of Wildlife Resources (1975b). The fishery was formerly of a world class nature throughout its length but has been adversely affected by human activity in the last few decades. Descriptions are given for the fishery in one section of designated Class I trout stream and two sections of designated Class II stream. All three sections supported a self-sustaining brown trout population and were stocked with rainbow trout. However, the Class I section had limited reproduction of rainbow trout and mountain whitefish.

The Utah Lake-Jordan River Basin was studied by the U.S. Environmental Protection Agency (1973) in a series of short-term, intensive water-quality studies during August 1972. General water quality was examined in 23 canals and tributaries that discharge to the Jordan River and at numerous sites on the river. In addition to measuring common water-quality constituents, surveys also were done for coliform bacteria, algae, benthic organisms, and fish at selected sites in the Jordan River from Utah Lake to Cudahy Lane in Davis County.

The aquatic, terrestrial, and sociological effects of a causeway completed in 1968 connecting Syracuse, Utah, to Antelope Island and the establishment of a State park on the island were investigated by a student group at the University of Utah (Carter, 1971). The aquatic ecosystem of Farmington Bay was examined to determine the effects of salinity, nutrients, and detergents on the biota. The causeway effectively created a less saline estuarine area where the Jordan River enters Great Salt Lake.

A survey of DDT and its isomers in fish from Utah Lake was reported by Eldredge (1967). Fish fat, flesh, and intestinal contents collected from white bass, black bullhead, common carp, and walleye were analyzed for DDT and dichloro-diphenyl-dichloro-ethylene (DDE). White bass was the most common species and was used as an indicator of periodic introductions of DDT and metabolites to the lake. The maximum concentration of total DDT in fish tissue was 2.87 parts per million (wet weight) from fish collected in August 1966.

The effects of organic material on benthic invertebrates in the Jordan River were examined by Hinshaw (1967) in one of the early water-quality studies. Physical and chemical water-quality data and samples of aquatic insects collected from the Jordan River in 1965 were compared to equivalent data collected during 1956-58. Communities of benthic invertebrates were not as diverse and numbers not as abundant in 1965 as they were earlier, so Hinshaw concluded that water quality declined from 1958-65. This was likely caused 
by an increase in biological oxygen demand (BOD) that correlated closely with a decrease in dissolved oxygen and the presence of unstable and fine-grained sediments.

Quinn (1958) studied the effects of waste from a sugar beet processing plant on periphyton in the Jordan River. A low concentration of dissolved oxygen was believed to be the most limiting factor. Diatoms and most other periphytic algae disappeared from the reach downstream from the plant in the fall and winter months when it was in operation; however, periphyton growth in the reach upstream from the plant was unaffected. After cessation of plant operation, the periphyton community recovered.

A comprehensive study to identify sources of pollution and the chemical and bacteriological quality of the Jordan, Price, Provo, and Weber Rivers was done by Gaufin (1957). At that time, the Jordan River was considered to be the most heavily polluted stream in the state. The upper and middle reaches of the Jordan River supported fish; however, the lower reach supported only the most tolerant fish and macroinvertebrates. Fish in the Provo River were not limited by the water quality, and the diversity of invertebrates was found to be "well balanced" at all sites. Conditions in the Weber River were considered to be "satisfactory to excellent" for fish and macroinvertebrates at most sites. However, water-quality problems did occur from raw sewage or seepage from refuse dumps, feed lots, and stables from a number of towns along the river. In the Weber River, downstream from Echo Reservoir, whitefish and suckers were dominant. The upstream reaches of Silver Creek, a tributary to the Weber River, were devoid of aquatic biota owing to contamination by mining waste from Park City. Trace-element concentration data for fish tissue were not presented.

The effects of organic loading to Mill Creek, a tributary of the Jordan River near Salt Lake City, were evaluated by Lemke (1954). Measurements of $\mathrm{pH}$, alkalinity, temperature, and dissolved oxygen were taken along with a semiquantitative evaluation of the benthic biota. Sites with an abundance of organic material were characterized by a low concentration of dissolved oxygen and reduced diversity and abundance of benthic organisms.

\section{Weber River Basin}

Pesticide concentrations (chlordane, DDD, DDE, DDT, dieldrin, and polychlorinated biphenyls (PCBs)) in bottom sediment at three sites in the lower Weber River drainage were reported by Thompson (1983) as part of a water-quality study. The sites (Hooper Slough, Howard Slough, and Weber River at 1150 South Street) were located in agricultural areas near the discharge of the Weber River to Ogden Bay. Chlordane concentration at the Weber River site was $6 \mu \mathrm{g} / \mathrm{kg}$ and PCB concentration was $5 \mu \mathrm{g} / \mathrm{kg}$. PCB concentration in sediment from Hooper Slough was $1 \mu \mathrm{g} / \mathrm{kg}$.

The effects of basin geology on the biological productivity of Smith and Morehouse Creek were investigated by Anderson (1963). Caddisflies were the most common macroinvertebrate, and diatoms the most common periphytic algae. Anderson concluded that the productivity of Smith and Morehouse Creek was low in comparison with other streams as a result of low bicarbonate levels attributed to quartzite rock and spring flushing of nutrients from the stream.

Jorgenson (1961) studied the productivity of macroinvertebrates in the Weber River upstream of the newly created Rockport Reservoir. He reported a significant positive correlation between carbonate/bicarbonate concentrations in the stream and abundance of macroinvertebrates along a downstream spatial gradient. Human activities were believed to be the most important factor controlling productivity of the stream.

A general survey of pollution in the Weber River was conducted by Smith (1959). Water and macroinvertebrates were sampled at four sites on Silver Creek downstream from Park City, and seven sites on the Weber River from Wanship to Uintah. Water-quality and benthic habitat conditions in Silver Creek were unsuitable for most aquatic life. Within the Weber River, sewage outfalls from several small towns were present, but aquatic life appeared to be relatively unimpaired, probably because of dilution of wastewater effluents by the river. Overall, it was found that the most detrimental impact to aquatic life in the Weber River was from habitat degradation, resulting from siltation, dredging of the stream bottom, and flow diversions. 


\section{Bear River Basin}

The National Pesticide Monitoring Program was established by the Bureau of Sport Fisheries (forerunner of the U.S. Fish and Wildlife Service) in the mid1960s to determine organochlorine insecticide residues in fish nationwide. Initially, 50 monitoring sites were established. In 1967, the program became the National Contaminants Biomonitoring Program and was expanded during the next 8 years to include a total of 115 sites, and PCBs and trace elements were added to the contaminant list. Two sites within the GSLB study unit were monitored: (1) Utah Lake at Provo (1960 through 1986), and (2) Bear River at Preston, Idaho (1970 through 1973) and at Brigham City (1976 through 1986). Typically, fish were collected every 2 years as composite samples of three to five whole fish, and analyzed for arsenic, cadmium, copper, lead, mercury, selenium, zinc, and up to 22 chlorinated pesticides and PCBs. Tissue-concentration data for the two sites in the study unit area are summarized by Henderson and others (1972), Schmitt and others (1981), Schmitt and others (1983), Schmitt and Brumbaugh (1990), Schmitt and others (1990), and Schmitt (U.S. Fish and Wildlife Service, written commun., 1990).

Waddell and others (1990) collected sediment and water samples from areas north of the Bear River Migratory Bird Refuge to determine the presence of contaminants. Samples were collected from Black Slough, Chesapeake Gun Club, Public Shooting Grounds, Sulphur Creek, Whistler Canal, and an area near the refuge headquarters and were analyzed for a suite of trace elements and chlorinated pesticides. Concentrations of pesticides and organochlorine compounds in bottom sediment were generally below detection limits or at very low levels except for DDT and its metabolites. The highest concentrations of DDD $(13 \mu \mathrm{g} / \mathrm{kg})$ and DDE $(17 \mu \mathrm{g} / \mathrm{kg})$ were found at Black Slough. Concentrations of trace elements in water from each of the sites were less than applicable water-quality standards.

Organochlorine pesticides and PCBs were monitored in tissues and eggs of western grebes and wholebody fish at the Bear River Migratory Bird Refuge (Lindvall and Low, 1979). This report provides a good background on organochlorine pesticides in marshes in the late 1970s. DDE was the predominant contaminant found in both birds and fish, and concentrations of DDE ranged from 5.4 to $213 \mathrm{ppm}$ wet weight in visceral fat of grebes. DDE concentrations in common carp, catfish, and Utah chub did not exceed 0.02 ppm (wet weight, whole fish). PCBs (Aroclor numbers 1254 and 1260) were not detected in fish, but were found at concentrations of $5.4 \mathrm{ppm}$ (wet weight) or less in grebe eggs. No direct mortality of birds from pesticide poisoning was documented at the refuge.

Adams and others (1975) completed a field study of naturally occurring organic compounds and their effects on aquatic biota in Hyrum Reservoir in the Bear River drainage. Naturally occurring organic compounds (acetaldehyde, methanol, ethanol, propanol, acetone, and 2-propanol) were identified and monitored in the reservoir. No effects on aquatic biota were observed at the concentration levels found in water from the reservoir.

\section{Lakes}

The two principal lakes in the study area are Utah Lake, at the head of the Jordan River, and Bear Lake in the Bear River drainage, on the Utah-Idaho border. Selected studies on these lakes are included in this report (table 6).

\section{Utah Lake}

Utah Lake, like Great Salt Lake, is a remnant of ancient Lake Bonneville, which covered much of Utah until about 9,000 years ago. Utah Lake is a shallow, freshwater lake, which frequently experiences high turbidity and extensive algal blooms. It is a popular fishing resource and numerous non-native game fish have been introduced which have reduced the native assemblage of fish species in the lake. Both Cope and Yarrow (1875) and Jordan (1891) noted that Bonneville cutthroat trout, whitefish, and suckers from Utah Lake were abundant and important food sources for the early settlers. These species have now declined or been eradicated from the lake. The current assemblage consists of carp and various warm water game fish, including white bass, walleye, channel catfish, bluegill, large mouth bass, yellow perch, and black crappie.

In the late 1970s and early 1980s Utah Lake was the subject of many studies, in part to evaluate the 
Table 6. Selected investigations of Utah Lake and Bear Lake in the Great Salt Lake Basins study unit

\begin{tabular}{|c|c|c|c|c|c|c|}
\hline Reference & Utah Lake & Bear Lake & Fish & $\begin{array}{c}\text { Inverte- } \\
\text { brates }\end{array}$ & $\begin{array}{c}\text { Algae/ } \\
\text { plankton }\end{array}$ & General description \\
\hline Barnes and Toole, 1981 & $\mathrm{x}$ & & & $\mathrm{x}$ & & Literature review of macroinvertebrate and zooplankton communities \\
\hline Birdsey, 1989 & & $\mathrm{x}$ & & & & Limnology literature review \\
\hline Brigham Young University, 1975 & $\mathrm{x}$ & & & & & $\begin{array}{l}\text { Review of environmental studies for Jordanelle Reservoir site, Utah Lake, Provo, and Jor- } \\
\text { dan Rivers }\end{array}$ \\
\hline Carter, 1969 & $\mathrm{x}$ & & $\mathrm{x}$ & & & History of commercial fishing in Utah Lake \\
\hline Eldredge, 1967 & $\mathrm{x}$ & & $\mathrm{x}$ & & & Concentration of DDT and its derivatives in fish tissues \\
\hline Environmental Dynamics, 1975 & $\mathrm{x}$ & & $\mathrm{x}$ & $\mathrm{x}$ & $\mathrm{x}$ & History of fish stocking, populations, and other biological information \\
\hline Eyring Research Institute, Inc., 1982 & $\mathrm{x}$ & & $\mathrm{x}$ & $\mathrm{x}$ & $\mathrm{x}$ & Water quality, hydrology, and aquatic biology assessment of Utah Lake \\
\hline Harding, 1971 & $\mathrm{x}$ & & & & $\mathrm{x}$ & Description of algae population \\
\hline Heckmann and Merritt, 1981 & $\mathrm{x}$ & & $\mathrm{x}$ & $\mathrm{x}$ & $\mathrm{x}$ & Geology, setting, hydrology, and biotic communities of Utah Lake \\
\hline Kemmerer and others, 1923 & & $\mathrm{x}$ & $\mathrm{x}$ & $\mathrm{x}$ & $\mathrm{x}$ & Description of fish, plankton, and algae and examination of stomach contents of fish \\
\hline Lamara and others, 1986 & & $\mathrm{x}$ & $\mathrm{x}$ & $\mathrm{x}$ & $\mathrm{x}$ & Hydrology and impact on trophic state \\
\hline Lowder, 1951 & $\mathrm{x}$ & & $\mathrm{x}$ & & & Taxonomic study of catostomidae (suckers) \\
\hline Moreno, 1989 & & $\mathrm{x}$ & & $\mathrm{x}$ & & Seasonal variations in zooplankton community \\
\hline Nielson and Lentsch, 1988 & & $\mathrm{x}$ & $\mathrm{x}$ & & & Status and management of Bear Lake cutthroat trout \\
\hline Nielson, 1994 & & $\mathrm{x}$ & $\mathrm{x}$ & & & Sport fish stocking activities, $1975-89$ \\
\hline Perry, 1943 & & $\mathrm{x}$ & $\mathrm{x}$ & & & Biology and significance of peaknose cisco \\
\hline Radant and Sakaguchi, 1981 & $\mathrm{x}$ & & $\mathrm{x}$ & & & Fish inventory \\
\hline Ruzycki and Wurtsbaugh, 1995 & & $\mathrm{x}$ & $\mathrm{x}$ & & & Forage fish populations \\
\hline Ruzycki, 1995 & & $\mathrm{x}$ & $\mathrm{x}$ & & & Habitat of Bear Lake sculpin \\
\hline Smart, 1958 & & $\mathrm{x}$ & & $\mathrm{x}$ & & Ecology of benthic fauna \\
\hline White, 1974 & & $\mathrm{x}$ & $\mathrm{x}$ & & & Systematics of Bear Lake whitefish species \\
\hline Wurtsbaugh and Hawkins, 1990 & & $\mathrm{x}$ & $\mathrm{x}$ & $\mathrm{x}$ & & Trophic interactions in Bear Lake \\
\hline Wurtsbaugh and Luecke, 1994 & & $\mathrm{x}$ & $\mathrm{x}$ & & & Abundance and distribution of forage fish \\
\hline Wurtsbaugh and Neverman, 1988 & & $\mathrm{x}$ & $\mathrm{x}$ & & & Diel vertical migration of juvenile Bear Lake sculpin \\
\hline Wurtsbaugh, 1998 & & $\mathrm{x}$ & $\mathrm{x}$ & $\mathrm{x}$ & $\mathrm{x}$ & Effects of water diversion on trophic status of Bear Lake \\
\hline
\end{tabular}


effects of the Central Utah Project, a large reclamation project that affected the Provo River drainage. A monograph covering the geology, hydrology, and biotic communities in the lake and surrounding watershed was published in 1981 by Heckmann and Merritt. The Eyring Research Institute, Inc. (1982) also published a document on the water quality, hydrology, and aquatic biology of Utah Lake, and Environmental Dynamics (1975) published a history of fish stocking in Utah Lake as part of an evaluation of the Jordan River system. Barnes and Toole (1981) published a literature review of macroinvertebrate and zooplankton studies in the lake, and Radant and Sakaguchi (1981) reported on the fish populations of the lake. In earlier studies, Harding (1971) published an account on the diatom community, and Carter (1969) reported a history of commercial fishing operations and their effects on the fishery.

\section{Bear Lake}

Bear Lake is a large, deep, freshwater lake that is formed in a graben valley. It has existed for more than 28,000 years. At one time, the lake was connected to the Bear River, but it was isolated when the river changed course after the last glaciation. In the early 1900s, humans connected the lake and river again through a series of diversions created for water storage purposes. The lake is very oligotrophic and an alkaline chemical environment has contributed to a unique assemblage of fish species in the lake. Four endemic species naturally occur in the lake; the Bonneville cisco, Bonneville whitefish, Bear Lake sculpin, and Bear Lake whitefish. Bear Lake also is a stronghold of the lacustrine form of the Bonneville cutthroat trout, and is one of the only places this species has survived. Populations of cutthroat trout and non-native lake trout are sustained through a stocking program.

Other introductions of exotic species into Bear Lake have not been particularly successful, partly as a result of the chemical environment, although many introductions have been attempted. A few exotic species, other than the lake trout, still are present in the lake, but not in large numbers. The lake is heavily used as a recreational resource and is well known for its distinct blue-green color, caused by the precipitation of calcium carbonate. The effects of diverting the Bear River, which has a high sediment and nutrient load, into Bear Lake are a source of great interest on the part of both the public and researchers (Wurtsbaugh, 1998).
One of the earliest records of the biology of Bear Lake is by Kemmerer in his survey of lakes of the Western United States (Kemmerer and others, 1923). This study examined fish populations, made notes on their diets, and noted the abundance of zooplankton and phytoplankton. The fish populations of the lake have received much attention. The systematics of the whitefish species in the lake, of which two are endemic, were summarized by White (1974). The natural histories of forage fish in the lake have been the subject of more recent studies (Ruzycki and Wurtsbaugh, 1995; Wurtsbaugh and Luecke, 1994; Wurtsbaugh and Neverman, 1988; Ruzycki, 1995) as part of an overall effort to establish the trophic interactions of the aquatic populations (Wurtsbaugh and Hawkins, 1990; Lamara and others, 1986). Birdsey (1989) provided a literature review of the limnology of the lake, and Moreno (1989) examined the zooplankton communities.

\section{SUMMARY}

Investigations of aquatic communities, aquatic species of special concern, aquatic habitat, and contaminants in riverine systems, and in Bear and Utah Lakes within the Great Salt Lake Basins study unit have been summarized in tables and figures. Literature selected for inclusion is published in a variety of formats including journal articles and conference proceedings, government reports, university documents, theses, dissertations, and books.

Historically, the fish population of the Great Salt Lake Basins study unit was not particularly diverse and consisted mostly of forage species with only a few predator species. Since the settlement of the study area by pioneers in the late 1800 s, non-native game and forage species have been introduced for food and sport. Many native species in the study unit area have declined in numbers or been eliminated as a result of the introduction of non-native fishes. Macroinvertebrate and algal communities have been examined in many parts of the study unit, but long-term monitoring programs are scarce. As such, information on long-term trends in macroinvertebrate and algal communities in the study unit is lacking. However, the use of macroinvertebrates in water-quality monitoring has gained popularity in recent years and most State agencies now incorporate macroinvertebrate studies into their moni- 
toring plans. These efforts will greatly augment the base of information on macroinvertebrate communities in the study unit. Algal populations continue to be neglected as a source of water-quality data, although some monitoring efforts now include samples of periphyton along with macroinvertebrates.

Most of the existing biological studies examined the population or community structure of fish, invertebrates, or algae, or examined the life history of a species or group of species. Although information on fish and macroinvertebrates is extensive in some areas of the study unit, information on algal populations is generally limited. Among species of special concern, the Bonneville cutthroat trout is the most extensively studied. The status of this subspecies of the inland cutthroat trout is now largely established, although analyses are underway to determine the genetic purity of specific populations. The June sucker, least chub, leatherside chub, and spotted frog also are species of special concern in the study unit. Aquatic habitat data are sometimes collected in conjunction with the biological data, and information is available at some locations about the effects of channel modifications on aquatic communities.

Data on contamination of sediments or fish tissues generally is limited to the Jordan River basin and areas near Great Salt Lake. Utah Lake has been greatly affected by the stocking of exotic fish species and agricultural and urban runoff. Bear Lake has been less affected by these problems because of its large volume, distance from large population centers, and unique chemical environment. The information contained in this report will be useful to students and professionals studying stream water quality and aquatic biology in the Great Salt Lake Basins study unit of the National Water-Quality Assessment Program.

\section{REFERENCES}

Adams, V.D., Renk, R.R., Cowan, P.A., and Precella, D.B., 1975, Naturally occurring organic compounds and algal growth in a eutrophic lake: Utah Water Research Laboratory Report PRWG137-1, Utah State University, Logan, Utah, 140 p.

Adamus, P.R., 1975, Dynamics of drift and benthos: diversity and environmental influences in Mill Creek, Salt Lake County, Utah: Salt Lake City,
University of Utah, Master of Science thesis, 136 p.

Alstad, D.N., 1978, Distributional and community ecology of filtering caddisflies (Trichoptera: Hydropsychidae): Salt Lake City, University of Utah, Ph.D. dissertation, 86 p.

Anderson, M.A., 1963, A study of the productivity of macroinvertebrates and periphyton in the Smith and Morehouse Creek, Summit County, Utah: Salt Lake City, University of Utah, Master of Science thesis, $70 \mathrm{p}$.

Andreasen, J.D., and Barnes, J.R., 1975, Reproductive life history of Catostomus ardens and C. discobolus in the Weber River, Utah: Copeia, p. 643-648.

Bailey, R.G., and Larson, N.D., 1968, Provo River channel deterioration and stability problems associated with the Duchesne tunnel: U.S. Forest Service, Wasatch-Cache National Forest, Salt Lake City, Utah.

Bangerter, A., 1966, Blacksmith Fork river fisheries investigations: Utah Division of Wildlife Resources, Salt Lake City, Utah, 19 p.

Barnes, J.R., and Toole, T.W., 1981, Macroinvertebrate and zooplankton communities of Utah Lake: a review of the literature: Great Basin Naturalist Memoirs, v. 5, p. 101-106.

Baumann, R.W., 1967, A study of the stoneflies (Plecoptera) of the Wasatch Front, Utah: Salt Lake City, University of Utah, Master of Science thesis, $111 \mathrm{p}$.

Baxter, G.T., and Simon, J.R., 1970, Fishes of Wyoming (revised): Wyoming Game and Fish Department Bulletin Number 4, Cheyenne, Wyo., 168 p.

Baxter, G.T., and Stone, M.D., 1995, Wyoming Fishes: Wyoming Game and Fish Department, Cheyenne, Wyo., 129 p.

Beers, G.D., 1969, Rates of algal production and Sphaerotilus assimilation in the Logan River, Utah: Logan, Utah, Utah State University, Ph.D. dissertation, $73 \mathrm{p}$.

Behmer, D.J., and Hawkins, C.P., 1986, Effects of overhead canopy on macroinvertebrate production in a Utah stream: Freshwater Biology, v. 16, p. 287300.

Behnke, R.J., 1976, Summary of information on the status of the Utah or Bonneville cutthroat trout, Salmo clarki utah: Report to the U.S. Forest Service, Wasatch-Cache National Forest, Salt Lake City, Utah. 
1979, Monograph of the native trouts of the genus Salmo of western North America: U.S. Fish and Wildlife Service, Washington, D.C.

1980, Purity evaluation of Bear River cutthroat trout from Mill and Carter Creeks, Wasatch National Forest, Summit County, Utah: U.S. Forest Service Report to Wasatch-Cache National Forest, Salt Lake City, 10 p.

1988, Phylogeny and classification of cutthroat trout, in American Fisheries Society Symposium, v. 4 , p. 1-7.

1992, Native trout of western North America: Bethesda, MD, American Fisheries Society, 275 p.

Behnke, R.J., and Proebstel, D.S., 1994, Analysis of cutthroat trout from the Bonneville Basin, Idaho: U.S. Forest Service, Caribou National Forest, Pocatello, Idaho, $20 \mathrm{p}$.

Bergersen, E.P., 1973, Fish production and movements in the lower Logan River, Utah: Logan, Utah, Utah State University, Ph.D. dissertation, 169 p.

Bernard, D.R., 1976, Reproduction by adfluvial salmonids in Spawn Creek, Cache County, Utah: Logan, Utah, Utah State University, Master of Science Thesis, $84 \mathrm{p}$.

Bernard, D.R., and Israelsen, E.K., 1982, Inter- and intra-stream migration of cutthroat trout (Salmo clarki) in Spawn Creek, a tributary of the Logan River, Utah: Northwest Science, v. 56, no. 2, p. 148-158.

Bickel, D., 1977, A survey of locally endemic Mollusca of Utah, Colorado, Wyoming, Montana, North Dakota and South Dakota: Submitted to the U.S. Department of the Interior, Fish and Wildlife Service, Office of Endangered Species in fulfillment of Contract No. 14-16-0006-3030.

Binns, N.A., 1977, Present status of indigenous populations of cutthroat trout, (Salmo clarki), in southwest Wyoming: Wyoming Game and Fish Department Technical Bulletin 2, Cheyenne, Wyo. 1981, Bonneville cutthroat trout (Salmo clarki utah) in Wyoming: Wyoming Game and Fish Department Fisheries Technical Bulletin 5, Cheyenne, Wyo.

Binns, N.A., and Eiserman, F.M., 1979, Quantification of fluvial trout habitat in Wyoming: Transactions of the American Fisheries Society, v. 108, no. 3, p. 215-228.

Binns, N.A., and Remmick, R., 1994, Response of Bonneville cutthroat trout and their habitat to drainagewide habitat management at Huff Creek, Wyo- ming: North American Journal of Fisheries Management, v. 14 , no. 4, p. 669-680.

Birdsey, W.P., Jr., 1989, The limnology of Bear Lake, Utah-Idaho, 1912-1988: A literature review: Utah Division of Wildlife Resources Publication No. 89-5, Salt Lake City, Utah, 113 p.

Bissonette, J.A., and Larsen, B.C., 1991, Annotated bibliography for the spotted frog (Rana pretiosa): Utah Cooperative Fish and Wildlife Research Unit Miscellaneous Report 91 (2), Logan, Utah, 20 p.

Bridges, D.W., 1963, Abundance, movements, harvest and survival of brown trout and mountain whitefish in a section of Logan River: Logan, Utah, Utah State University, Master of Science thesis, 55 p.

Brigham Young University Center for Health and Environmental Studies, 1975, Final phase I, environmental studies of the proposed Jordanelle Reservoir site, Provo River, Utah Lake, Jordan River and proposed Lampton Reservoir site: Provo, Utah, Brigham Young University. -1976, Survey of macroinvertebrate communities in the Provo River and Diamond Fork systems: Utah Division of Wildlife Resources, Salt Lake City, Utah.

Brooks, G.D., 1955, The Chironomidae of the Provo River: Salt Lake City, University of Utah, Master of Science thesis, $49 \mathrm{p}$.

Brown, C., 1935, A survey of the waters of the Cache National Forest, Utah: Department of Commerce, Bureau of Fisheries, 31 p.

Brown, L.G., 1972, Early life history of the Mountain Whitefish, Prosopium williamsoni (Girard), in the Logan River, Utah: Logan, Utah, Utah State University, Master of Science thesis, $39 \mathrm{p}$.

Bulloch, E.C., 1969, A comparison of certain aspects of the ecological life histories of 2 Dace (Rhinichthys) in the Weber River, Utah: Salt Lake City, University of Utah, Master of Science thesis, $28 \mathrm{p}$.

Carbine, W.F., 1936, The life history of the chub, Tigoma ataria (Girard): of the Great Basin area of Utah: Salt Lake City, University of Utah, Master of Science thesis, $107 \mathrm{p}$.

Carter, C.K., 1971, Some ecological considerations of the Farmington Bay estuary and adjacent Great Salt Lake Park: Salt Lake City, University of Utah, 249 p.

Carter, D., 1969, A history of commercial fishing on Utah Lake: Provo, Utah, Brigham Young University, Master of Arts thesis, $142 \mathrm{p}$.

Cather, M.R.C., 1974, Life history and ecology of selected species of stoneflies (Plecoptera) of Mill 
Creek, Wasatch Mountains, Utah: Salt Lake City, University of Utah, Ph.D. dissertation, 175 p.

CH2M Hill, 1992, Jordan River Stability Study -

DRAFT: Submitted to Salt Lake County, Salt Lake City, variously paged.

1995, Draft environmental contaminants study for Spanish Fork Canyon/Nephi irrigation system: Report SAC/109164/023.doc, 5 numbered sections.

Christensen, E.M., 1956, Bibliography of Utah aquatic biology: Proceedings of the Utah Academy of Science, Arts and Letters, v. 33, p. 91-100.

1962, Bibliography of Utah aquatic biology, No. II: Great Basin Naturalist, v. 22, p. 32-53.

Chrostowski, H.P., 1972, Central Utah Project: Stream habitat studies on the Uinta and Ashley National Forests: U.S. Forest Service Intermountain Region, Ogden, Utah.

Clark, W.J., 1958, The phytoplankton of the Logan River, Utah, a mountain stream: Logan, Utah, Utah State University, Ph.D. dissertation, 95 p.

Coombs, R.E., 1964, A floristic and ecological survey of the algal flora of the western Uinta Mountains and adjacent areas: Salt Lake City, University of Utah, Master of Arts thesis, $76 \mathrm{p}$.

Cope, E.D., and Yarrow, H.C., 1875, Report on the collections of fishes made in portions of Nevada, Utah, California, Colorado, New Mexico and Arizona during the years 1871, 1872, 1873 and 1874: Report on the geographic and geologic exploration and survey west of the 100th meridian (Wheeler Survey), v. 5, p. 635-703.

Cope, O.B., 1955, The Future of the cutthroat in Utah, in Harrison, G.L., ed., Proceedings of the Utah Academy of Sciences, Arts and Letters, v. 32, p. 89-93.

Cowley, P.K., 1994, Fish surveys of the Caribou National Forest: U.S. Forest Service, Salt Lake City, Utah, 23 p. 1995, Fish surveys on the Wasatch-Cache National Forest: U.S. Forest Service, Salt Lake City, Utah, 65 p.

1997a, Fish surveys on the Uinta and WasatchCache National Forest conducted during 1996: U.S. Forest Service, Salt Lake City, Utah, 38 p. 1997b, Fish surveys on the Wasatch-Cache National Forest conducted during 1997: Uinta and Wasatch-Cache National Forest, Salt Lake City, Utah, $14 \mathrm{p}$.

Crawford, M., 1979, Reproductive modes of the least chub (Iotichthys phlegethontis - Cope): Logan,
Utah, Utah State University, Master of Science thesis, $78 \mathrm{p}$.

Crist, L.W., and Holden, P.B., 1991, Preliminary annual report - 1990 Fishery Investigation of the lower Jordan River: BIO/WEST, Inc. submitted to: Central Valley Water Reclamation Board PR-166-4, Logan, Utah, $21 \mathrm{p}$.

Crowl, T.A., Petersen, M.E., and Mellenthin, R., 1995a, Trophic interactions of gizzard shad, June sucker and white bass: Implications for fishery enhancement and the management of the endangered June sucker: Utah State University Report for the Utah Division of Wildlife Resources, Project F-46-R, Segment 6, Logan, Utah, $54 \mathrm{p}$.

Crowl, T.A., Thomas, H.M., and Thiede, G., 1995b, June sucker studies-1995: Provo River and Utah Lake fisheries management studies: Utah State University, Annual Report to Utah Division of Wildlife Resources, Logan, Utah.

Duff, D.A., 1988, Bonneville cutthroat trout: Current status and management, in Gresswell, R.E., ed., Status and management of interior stocks of cutthroat trout: Bethesda, Md., American Fisheries Society Symposium, v. 4, p. 121-127.

1996, Conservation assessment for inland cutthroat trout, distribution, status and habitat management implications: U.S. Department of Agriculture, Forest Service Intermountain Region, Ogden, Utah, 96 p.

Dunstan, W.A., 1951, A comparative study of a dredged and undredged portion of the Provo River, Utah: Salt Lake City, University of Utah, Master of Science thesis, $51 \mathrm{p}$.

EDAW, Inc., 1979, Jordan River Basin, Utah, Environmental Inventory: prepared for U.S. Army Corps of Engineers, Contract No. DACW05-79-D-0017, Sacramento, Calif., 62 p.

Edmunds, G.F., Jr., 1954, The Mayflies of Utah: Proceedings of the Utah Academy of Sciences, Arts and Letters, v. 31, p. 64-66.

Eldredge, J.D., 1967, The effects of time and age on DDT concentration in the diet of the white bass, Roccus chrysops, of Utah Lake: Salt Lake City, University of Utah, Master of Science thesis, $20 \mathrm{p}$.

Environmental Dynamics, 1975, An Environmental evaluation of the Utah Lake - Jordan River basin, final report: Submitted to National Commission on Water Quality WQ5AC071, Los Angeles, Calif.

Erman, N.A., 1968, Occurrence and distribution of invertebrates in Lower Logan River: Logan, Utah, 
Utah State University, Master of Science thesis, 80 p.

Eyring Research Institute, Inc., 1982, Water quality, hydrology and aquatic biology of Utah Lake: WHAB Phase I summary: Bureau of Reclamation, Provo, Utah, $170 \mathrm{p}$.

Floener, G.G., 1950, Life history of the cutthroat trout (Salmo clarkii richardson) in the Logan River, Utah: Logan, Utah, Utah State Agricultural College, Master of Science thesis, $82 \mathrm{p}$.

Gaufin, A.R., 1949, A comparative study of bottom fauna of the North and South Forks of the Provo River at Stewart's Ranch, Utah: Proceeding of the Utah Academy of Sciences, Arts and Letters, v. 26, no. 1.

1955, The Stoneflies of Utah, in Harrison, G.L., ed., Proceedings of the Utah Academy of Sciences, Arts and Letters, v. 32, p. 117-120.

1957, Limnological analysis of Jordan, Price, Provo and Weber Rivers: Salt Lake City, Utah, University of Utah, $7 \mathrm{p}$.

1959, Production of bottom fauna in the Provo River, Utah: Iowa State College Journal of Science, v. 33, no. 3, p. 395-419.

1964, Systematic list of Plecoptera of Intermountain region: Proceedings of the Utah Academy of Sciences, Arts and Letters, v. 41, no. 2, p. 221-227.

Gaufin, A.R., Nebeker, A.V., and Sessions, J., 1966, The Stoneflies of Utah: University of Utah Biological Series, v. 14, no. 1, p. 1-93.

Geer, W.H., 1981, Assessment of trout fishery conditions in Little Cottonwood Creek: Utah Division of Wildlife Resources, Salt Lake City, Utah.

Gilliom, R.J., Alley, W.M., and Gurtz, M.E., 1995, Design of the National Water-Quality Assessment Program: Occurrence and distribution of waterquality conditions: U.S. Geological Survey Circular 1112, Sacramento, Calif., 33 p.

Gosse, J.C., 1981, Brown trout (Salmo trutta) response to stream channel alterations, their microhabitat requirements, and a method for determining microhabitat in lotic systems: Logan, Utah, Utah State University, Ph.D. dissertation.

Gosse, J.C., and Helm, W.T., 1979, Effects of flow alterations on brown trout microhabitat in the Provo River: U.S. Bureau of Reclamation, Salt Lake City, Utah.

Graham, J.E., 1950, A preliminary study of the gnats or midges of the tribe Tendipedini in northern Utah:
Salt Lake City, University of Utah, Master of Science thesis, $48 \mathrm{p}$.

Griffith, J.S., 1988, Review of competition between cutthroat trout and other salmonids, in Gresswell, R.E., ed., Status and management of interior stocks of cutthroat trout: American Fisheries Society Symposium, Bethesda, Md., v. 4, p. 134-140.

Gurtz, M.E., 1994, Design of biological components of the National Water-Quality Assessment (NAWQA) program, in Loeb, S.L., and Spacie, A., eds., Biological Monitoring of Aquatic Systems:

Boca Raton, Fla., Lewis Publishers, p. 323-354.

Gutermuth, F.B., Lentsch, L.D., and Stranger, M.C., 1993, June sucker reproductive biology in the Provo River, Utah: Utah Division of Wildlife Resources 1992 Progress Report (draft), Salt Lake City, Utah, 23 p.

Halpin, M.A., 1987a, Jordan River wetlands vegetation evaluation: Utah Division of Wildlife Resources, Salt Lake City, Utah, 46 p.

1987b, Jordan River wetlands wildlife evaluation: Utah Division of Wildlife Resources, Salt Lake City, Utah, 60 p.

Harding, W.J., 1971, The algae of Utah Lake, Part II: Great Basin Naturalist, v. 31, no. 3, p. 125-134.

Harvey, B.C., 1993, Benthic assemblages in Utah headwater streams with and without trout: Canadian Journal of Zoology, v. 71, p. 896-900.

Harvey, B.C., and Marti, C.D., 1993, The impact of dipper, Cinclus mexicanus, predation on stream benthos: Oikos, v. 68, p. 431-436.

Heckmann, R.A., and Merritt, L.B., 1981, Utah Lake Monograph: Provo, Utah, Brigham Young University, $169 \mathrm{p}$.

Helm, W.T., 1982, Defining stream fish microhabitat requirements for water project planning: Utah Center for Water Resources Research and the Ecology Center, Utah State University, Logan, Utah, $13 \mathrm{p}$.

Henderson, C., Inflis, A., and Johnson, W.L., 1972, Mercury residues in fish, 1969-1970 - National pesticide monitoring program: Pesticides Monitoring Journal, v. 6, p. 144-159.

Hickman, T.J., 1977, Status of Bonneville cutthroat trout, Salmo clarki utah: Colorado State University, Department of Fish and Wildlife, Fort Collins, Colo., 12 p.

1978, Systematic study of the native trout of the Bonneville basin: Fort Collins, Colo., Colorado State University, Master of Science thesis. 
1989, Status report of the least chub, Iotichthys phlegethontis: prepared for U.S. Fish and Wildlife Service, Western Ecosystems, St. George, Utah, $20 \mathrm{p}$.

Hinshaw, R.N., 1967, The pollutional degradation of the Jordan River as shown by aquatic invertebrates: Salt Lake City, University of Utah, Master of Science thesis, $121 \mathrm{p}$.

Holden, P.B., and Crist, L.W., 1987, Fishery and macroinvertebrate studies of the Jordan River in Salt Lake County, November 1986: prepared by BIO/WEST, Inc. for Central Valley Water Reclamation Facility Board, Salt Lake City, Utah, 92 p.

Holden, P.B., White, W., Somerville, G., Duff, D., Gervais, R., and Gloss, S., 1974, Threatened fishes of Utah: Utah Academy of Science, Arts and Letters, v. 2, no. 2, p. 46-65.

Holden, P.B., Zucker, S.J., Abate, P.D., and Valdez, R.A., 1996, Assessment of the effects of fish stocking in the State of Utah past, present and future: Prepared by BIO/WEST, Inc. for the Utah Division of Wildlife Resources, Logan, Utah, 104 p.

Hovingh, P., 1981, Leeches, mollusks and amphibians in the Intermountain region: Paleobiological and biogeographical considerations: University of Utah, Department of Biochemistry, Salt Lake City, Utah, 18 p.

-1987, Current status of the western spotted frog (Rana pretiosa) in the Bonneville Basin: Report to Utah Division of Wildlife Resources, Salt Lake City, Utah.

Hubbs, C.L., and Miller, R.R., 1948, The zoological evidence: correlation between fish distribution and hydrographic history in the desert basins of the Western United States: Bulletin of the University of Utah, v. 38, no. 20, p. 17-166.

Hubert, W.A., 1988, Survey of Wyoming crayfishes: Great Basin Naturalist, v. 48, no. 3, p. 370-372.

Hydroscience, Inc., 1977, Water quality review of major Jordan River tributaries: Prepared for Salt Lake County Council of Governments, Report to 208 Project, 43 p.

Idaho Department of Environmental Quality, 1998, Beneficial use reconnaissance project - 1998; Wadeable streams workplan: Boise, Idaho, $56 \mathrm{p}$.

Jensen, S.F., 1985, Assessment of Salt Lake Valley tributaries: Recreational use impairment and opportunities: Salt Lake County Public Works Division of Flood Control and Water Quality, Salt Lake City, Utah, $150 \mathrm{p}$.
1989, Jordan River Wetland Advance Identification Study: Salt Lake City-County Health Department, Division of Environmental Health, Bureau of Water Quality, Salt Lake City, Utah, $72 \mathrm{p}$.

1990, Wasatch Watershed Monitoring Network, 1989 Season Summary: Salt Lake City-County Health Department, Division of Environmental Health, Bureau of Water Quality and Hazardous Waste, Salt Lake City, Utah.

1991, Wasatch Watershed Monitoring Network, 1990 Season Summary: Salt Lake City-County Health Department, Division of Environmental Health, Bureau of Water Quality, and Hazardous Waste, Salt Lake City, Utah.

-1993, Ecological characterization and functional evaluation of subalpine and lower montane wetlands in the Albion basin of Utah: Board of Salt Lake County Commissioners, commission staff office, Salt Lake City, Utah, 45 p.

1995, Jordan River non-point source management plan for hydrologic modifications: Board of Salt Lake County Commissioners, commission staff office, Salt Lake City, Utah, 26 p.

Johnson, J.E., 1985, An inventory of Utah crayfish with notes on current distribution, in Leppink, J.D., ed., Proceedings of the Bonneville Chapter of the American Fisheries Society, Utah State University, Logan, Utah, January 30-31, 1985: Salt Lake City, Bonneville Chapter of American Fisheries Society, v. 1985 , p. $47-58$.

Johnson, J.B., Belk, M.C., and Shiozawa, D.K., 1995, Age, growth and reproduction of leatherside chub (Gila copei): Great Basin Naturalist, v. 55, no. 2, p. 183-187.

Jordan, D.S., 1891, Report of explorations in Colorado and Utah during summer of 1889, with an account of fishes found in each of the river basins examined: Bulletin of the United States Fisheries Commission, v. 9 (1889), p. 1-40.

Jorgenson, S.C., 1961, A limnological study of the upper Weber River, Summit County, Utah: Salt Lake City, University of Utah, Master of Science thesis, $83 \mathrm{p}$.

Kada, J., Heit, M., and Miller, K.M., 1994, Chronology of anthropogenic trace element input to four Utah lakes reconstructed using sediment cores: Water, Air and Soil Pollution, v. 75, p. 353-369.

Kemmerer, G., Bovard, J.F., and Boorman, W.R., 1923, Northwestern lakes of the United States: Biological and chemical studies with reference to possibil- 
ities in production of fish: Bulletin of the U.S.

Bureau of Fisheries, v. 39, p. 52-140.

Knowlton, G.F., and Harmston, F.C., 1938, Notes on Utah Plecoptera and Trichoptera: Entomology News, v. 49, p. 284-286.

Lamara, F., Liff, C., and Carter, J., 1986, Hydrology of Bear Lake basin and its impact on the trophic state of Bear Lake, Utah-Idaho: Great Basin Naturalist, v. 46, p. 690-705.

Lamarra, M.C., 1982, Status report of three Bonneville basin endemic fishes: prepared for the U.S. Fish and Wildlife Service, $27 \mathrm{p}$.

Lawson, L.L., and Rushforth, S.R., 1975, The Diatom flora of the Provo River, Utah, U.S.A.: Germany, Strauss \& Cramer, 149 p.

Lemke, A.E., 1954, A pollutional survey of Mill Creek, Salt Lake County, Utah: Salt Lake City, University of Utah, Master of Science thesis, $61 \mathrm{p}$.

Lindvall, M., and Low, J.B., 1979, Organochlorine pesticide and PCB residues in Western Grebes from Bear River Migratory Bird Refuge, Utah: Bulletin of Environmental Contamination and Toxicology, v. 22, p. 754-760.

Lium, B.W., 1969, The distribution of aquatic insects in stream and river provinces as determined by chemical, physical and hydrological factors: Salt Lake City, University of Utah, Ph.D. dissertation, 83 p.

Lowder, J., 1951, A taxonomic study of the Catostomidae of Utah Lake with notes on the fish population: Provo, Utah, Brigham Young University, Master of Science thesis, $45 \mathrm{p}$.

Lytle, C.M., 1994, Heavy metal bioaccumulation in Great Basin submersed aquatic macrophytes: Provo, Utah, Brigham Young University, Ph.D. dissertation, $201 \mathrm{p}$.

Madsen, M.J., 1931, Aquatic insects of City Creek: Salt Lake City, University of Utah, Master of Arts thesis, $113 \mathrm{p}$.

Mangum, F.A., 1995, Aquatic ecosystem inventory, Macroinvertebrate analysis: State of Utah, Department of Environmental Quality, Division of Water Quality Ambient Streams and Special Project Streams, $139 \mathrm{p}$.

Martin, M.A., and Shiozawa, D.K., 1982, The electrophoresis of isolated trout populations from selected Utah streams: Utah State Division of Wildlife Resources, Salt Lake City, Utah.

Martin, M.A., Shiozawa, D.K., Loudenslager, E.J., and Jensen, N., 1985, Electrophoretic study of cutthroat trout populations in Utah: Great Basin Naturalist, v. 45 , p. 677-687.
Matthews, J.E., and Neuhold, J.M., 1967, Water quality effects on fish movement and distribution: Proceedings of Utah Academy of Sciences, Arts and Letters, v. 44, no. 1, p. 275-297.

May, B.E., Leppink, J.D., and Wydoski, R.S., 1978, Distribution, systematics and biology of the Bonneville cutthroat trout, Salmo clarki utah: Utah Division of Wildlife Resources Publication 78-15, Ogden, Utah.

McArthur, J.V., and Barnes, J.R., 1988, Community dynamics of leaf litter breakdown in a Utah alpine stream: Journal of the North American Benthological Society, v. 7, no. 1, p. 37-43.

McConnell, W.J., and Sigler, W.F., 1958, Chlorophyll and productivity in a mountain river: Limnology and Oceanography, v. 4, p. 335-351.

Merkley, D.R., 1948, The adult caddisflies of the Provo River: Salt Lake City, University of Utah, Master of Arts thesis, $105 \mathrm{p}$.

Meyers, T.F., 1972, Aquatic invertebrate consumption by the major fish species in the Blacksmith Fork River: Logan, Utah, Utah State University, Master of Science thesis, $76 \mathrm{p}$.

Miller, D.D., 1977, Comprehensive survey of the Bear River drainage: Wyoming Game and Fish Department, Fisheries Division Completion report, Cheyenne, Wyo., $81 \mathrm{p}$.

Miller, R.R., 1960, Man and the changing fish fauna of the American Southwest: Papers of the Michigan Academy of Sciences, Arts and Letters, v. 46, p. 365-404.

Modde, T., and Muirhead, N., 1990, Emergence patterns and feeding behavior of larval June sucker: Utah Division of Wildlife Resources, final report for contract 90-0081, Salt Lake City, Utah. 1994, Spawning chronology and larval emergence of June Sucker (Chasmistes liorus): Great Basin Naturalist, v. 54, no. 4, p. 366-370.

Moffett, J.W., 1935, A quantitative study of bottom fauna in some Utah streams variously affected by erosion: Salt Lake City, University of Utah, Master of Arts thesis, $65 \mathrm{p}$.

Moreno, E.G., 1989, Seasonal variation in the species composition, abundance and size frequency distribution of zooplankton in Bear Lake, Utah-Idaho: Logan, Utah, Utah State University, Master of Science thesis, $112 \mathrm{p}$.

Mou-Sheng, C., and Rushforth, S.R., 1977, The algal flora of the campus of Brigham Young University, Provo, Utah: Great Basin Naturalist, v. 37, no. 3, p. 402-406. 
Nabrotzky, F., 1987, Macroinvertebrate analysis and water quality data for wetlands of the Jordan River in Salt Lake County: Salt Lake City-County Health Department, Division of Environmental Health, Bureau of Water Quality, Salt Lake City, 33 p.

Nebeker, A.V., 1966, The taxonomy and ecology of the family Capniidae (Plecoptera) of the Western United States: Salt Lake City, University of Utah, Ph.D. dissertation, $197 \mathrm{p}$.

Needham, J.G., and Christenson, R.O., 1927, Economic insects in some streams of northern Utah: Utah Agricultural Experiment Station Bulletin 201, Logan, Utah, 36 p.

Newell, R.L., and Minshall, G.W., 1976, An annotated checklist of the aquatic insects of southeastern Idaho, Part I, Plecoptera: Great Basin Naturalist, v. 36, no. 4, p. 501-504.

1977, An annotated list of the aquatic insects of southeastern Idaho, Part II: Trichoptera: Great Basin Naturalist, v. 37, no. 2, p. 253-257.

Nielson, B.R., 1994, Sport fishing stocking activities at Bear Lake, 1975-1989: Utah Department of Natural Resources, Division of Wildlife Resources, Salt Lake City, 39 p.

Nielson, B.R., and Lentsch, L.D., 1988, Bonneville cutthroat trout in Bear Lake: Status and management, in Gresswell, R.E., ed., Status and management of interior stocks of cutthroat trout: American Fisheries Society Symposium, v. 4, p. 128-133.

Nielson, B.R., and Tolentino, S.A., 1996, Bear Lake cutthroat trout enhancement project: January 1990-December 1994: Utah Division of Wildlife Resources, Report No. 96-23.

Norrington, A., 1925, Phycological study of some of the mountain lakes and streams of the Wasatch and Uinta Ranges in Utah: Chicago, Ill., University of Chicago, Ph.D. dissertation.

Oberndorfer, R.Y., McArthur, J.V., and Barnes, J.R., 1984, The effect of invertebrate predators on leaf litter processing in an alpine stream: Ecology, v. 65, no. 4, p. 1325-1331.

Olsen, D.S., Abate, P.D., and Holden, P.B., 1996, Flushing flow, algae and habitat studies of the lower Provo river, 1996: Prepared by BIO/WEST, Inc. for Utah Division of Wildlife Resources, Annual report PR-568-1, Logan, Utah, 34 p.

Osborn, T.G., 1981, Stream insect production as a function of alkalinity and detritus processing: Logan, Utah, Utah State University, Ph.D. dissertation, $182 \mathrm{p}$.
Perkins, M.J., and Lentsch, L.D., 1998, Conservation strategy for spotted frog: Utah Division of Wildlife Resources, Salt Lake City, Utah, 52 p.

Perkins, M.J., Lentsch, L.D., and Mizzi, J., 1997, Conservation agreement and strategy for Least Chub, Iotichthys phlegethontis: Utah Division of Wildlife Resources and U.S. Fish and Wildlife Service, Salt Lake City, Utah, 34 p.

Perry, E.L., 1943, Biology and economic significance of the peaknose cisco of Bear Lake, Idaho and Utah: Logan, Utah, Utah State University, Master of Science thesis, $229 \mathrm{p}$.

Peters, E.J., 1974, The effects of highway construction on the fish population in the Weber River near Henefer, Utah: Provo, Utah, Brigham Young University, Ph.D. dissertation.

Peterson, B.V., 1955, A preliminary list of the black flies (Diptera: Simuliidae) of Utah, in Harrison, G.L., ed., Proceedings of the Utah Academy of Sciences, Arts and Letters, v. 32, p. 113-115.

Pettengill, T.D., 1994, Summary of an angler survey for the Logan River, 30 May - 6 September, 1993: Utah Department of Natural Resources, Division of Wildlife Resources, Salt Lake City, Utah.

Poole, W.C., 1981, The ecological bioenergetics of Pteronarcys californica (Newport): Idaho State University, Ph.D. dissertation, 211 p.

Popov, B.H., and Low, J.B., 1953, Game, fur animal and fish introductions into Utah: State of Utah Department of Fish and Game, Publication no. 4: p. 1-85, figs. 1-21.

Qi, Y., and Heckmann, R.A., 1995, Morphological and host-symbiont studies of Trichodina tenuiformis and Apiosoma campanulatum infesting mottled sculpin (Cottus bairdi) from Provo River, Utah: Great Basin Naturalist, v. 55, no. 3, p. 258-266.

Quinn, B.G., 1958, The effects of sugar beet wastes upon the periphyton of the Jordan River, Salt Lake County, Utah: Salt Lake City, University of Utah, Master of Science thesis, $91 \mathrm{p}$.

Radant, R.D., 1976, Fisheries inventory of the Provo River system and Main Creek: Utah Division of Wildlife Resources, Salt Lake City, Utah, 258 p. 1986, History, ecology and management of the June Sucker, in Jauhola, C.A., ed., Proceedings of the Bonneville Chapter of the American Fisheries Society, Utah State University, Logan, Utah, March 5-6, 1986: Salt Lake City, v. 1986, p. 48-58. Radant, R.D., and Sakaguchi, D.K., 1981, Utah Lake fisheries inventory: Prepared by Utah Division of Wildlife Resources for U.S. Bureau of Reclama- 
tion Contract 8-07-40-S0634, Salt Lake City, Utah, $244 \mathrm{p}$.

Radant, R.D., and Shirley, D.S., 1987, June suckerUtah Lake Investigations: Prepared by Utah Division of Wildlife Resources for U.S. Bureau of Reclamation Contract 8-07-40-S0643, Modification no. 5, Salt Lake City, Utah, 46 p.

Radant, R.D., Wilson, M., and Shirley, D.S., 1987, June sucker-Provo River instream flow analysis: Prepared by Utah Division of Wildlife Resources for U.S. Bureau of Reclamation Contract 8-07-40S0634, Modification no. 4, Salt Lake City, Utah, $45 \mathrm{p}$.

Rees, D.M., 1945, Supplemental notes on mosquito fish in Utah, Gambusia affinis (Baird \& Girard): Copeia, v. 4, p. 236.

Reger, S.J., 1980, Effects of stream channel alterations on aquatic insect communities: Logan, Utah, Utah State University, Ph.D. dissertation, 168 p.

Remmick, R., 1982, A survey of native cutthroat populations and associated stream habitats in the Bridger-Teton National Forest: Wyoming Game and Fish Department, Cheyenne, Wyo., 168 p.

Remmick, R., Nelson, K., Walker, G., and Henderson, J., 1994, Bonneville cutthroat trout interagency five year management plan (1993-1997): Wyoming Game and Fish Department, Cheyenne, Wyo., 19 p.

Robins, C.R., Bailey, R.M., Bond, C.E., Brookes, J.R., Lachner, E.A., Lea, R.N., and Scott, W.B., 1991, Common and scientific names of fishes from the United States and Canada (5th ed.): American Fisheries Society Special Publication No. 20, $183 \mathrm{p}$.

Ross, D.A., and Peterson, C.R., 1998, A review of the habitat requirements of the Columbia spotted frog (Rana luteiventris) in the intermountain region and recommendations for the restoration of Columbia spotted frog habitat along the Middle Provo River: Utah Reclamation, Mitiation and Conservation Commission, Salt Lake City, Utah, 52 p.

Ross, D.A., Shirley, D.L., White, P.A., and Lentsch, L.D., 1993, Distribution of the spotted frog along the Wasatch Front in Utah, 1991-1992: Utah Division of Wildlife Resources, Native Wildlife Section Report 93-4, Salt Lake City, Utah, 24 p.

Rushforth, S.R., and Merkley, G.S., 1988, Comprehensive list by habitat of the algae of Utah, USA: Great Basin Naturalist, v. 48, no. 2, p. 154-179.

Ruzycki, J.R., 1995, Ontogenetic habitat shift of juvenile Bear Lake sculpin (Cottus extensus): Logan,
Utah, Utah State University, Master of Science thesis, $51 \mathrm{p}$.

Ruzycki, J.R., and Wurtsbaugh, W.A., 1995, Examination of the factors controlling the abundance of Bear Lake forage fishes: Piscivore population and consumption estimates: Idaho Department of Fish and Game, $47 \mathrm{p}$.

Salevurakis, J.M., 1974, Rates of food digestion by brown trout (Salmo trutta) in the Blacksmith Fork River, Utah: Logan, Utah, Utah State University, Master of Science thesis, $50 \mathrm{p}$.

Samuelson, J.A., 1950, A quantitative comparison of the algal populations in two Wasatch mountain streams: Salt Lake City, University of Utah, Master of Science thesis, $45 \mathrm{p}$.

Schmidt, B.R., Birdsey, P.W., Jr., and Nielson, B.R., 1995, A conceptual management plan for cutthroat trout in Utah: Utah Division of Wildlife Resources Publication no. 95-7, Salt Lake City, Utah, 47 p.

Schmitt, C.J., and Brumbaugh, W.G., 1990, National contaminant biomonitoring program: Concentrations of arsenic, cadmium, copper, lead, mercury, selenium and zinc in U.S. freshwater fish, 19761984: Archives of Environmental Contamination and Toxicology, v. 19, p. 731-747.

Schmitt, C.J., Ludke, J.L., and Walsh, D.F., 1981, Organochlorine residues in fish: National Pesticide Monitoring Program, 1970-74: Pesticides Monitoring Journal, v. 14, p. 136-206.

Schmitt, C.J., Ribick, M.A., Ludke, J.L., and May, T.W., 1983, National pesticide monitoring program: Organochlorine residues in freshwater fish, 1976-79: U.S. Fish and Wildlife Service Resource Publication 152, $62 \mathrm{p}$.

Schmitt, C.J., Zajicek, J.L., and Peterman, P.H., 1990, National contaminant biomonitoring program: Residues of organochlorine chemicals in U.S. freshwater fish, 1976-1984: Archives of Environmental Contamination and Toxicology, v. 19, p. 748-781.

Scully, R.J., 1993, Bonneville cutthroat trout in Idaho: 1993 status: Idaho Department of Fish and Game Administrative Report, Boise, Idaho.

1994, Habitat conservation assessment and strategy, Bonneville cutthroat trout (Oncorhynchus clarki utah): Idaho Department of Fish and Game, Pocatello, Idaho.

Sessions, J., 1960, A study of the stoneflies of the Provo River, Utah: Salt Lake City, University of Utah, Master of Science thesis, $145 \mathrm{p}$. 
Shaw, M.A., 1986, Habitat management for classified species on the Wasatch-Cache National Forest, in Jauhola, C.A., ed., Proceedings of the Bonneville Chapter of the American Fisheries Society, Utah State University, Logan, Utah, March 5-6, 1986: Salt Lake City, Utah, v. 1986, p. 1-14.

Shiozawa, D.K., and Evans, R.P., 1995, The genetic status of cutthroat trout from various drainages in the Wasatch-Cache National Forest based on examination of mitochondrial DNA: U.S. Forest Service Interim report to Wasatch-Cache National Forest, Report Number 43-8490-4-0110, Salt Lake City, Utah, $17 \mathrm{p}$.

Shiozawa, D.K., Evans, R.P., and Williams, R.N., 1993, Relationships between cutthroat trout populations from ten Utah streams in the Colorado River and Bonneville drainages: Utah Division of Wildlife Resources, Interim Report, Odgen, Utah.

Shirley, D.S., 1983, Spawning ecology and larval development of the June sucker, in Proceedings of the Bonneville Chapter of the American Fisheries Society, Salt Lake City, Utah, vpp. 18-36.

Shirley, D.L., 1993, Translocation of spotted frogs from the Jordanelle Reservoir basin, Wasatch County, Utah: Utah Division of Wildlife Resources Publication Number 93-7, Springville, Utah, 11 p.

Sigler, J.W., and Sigler, W.F., 1994, Fishes of the Great Basin and the Colorado Plateau: Past and present forms, in Harper, K.T., St. Clair, L.L., Thorne, K.H., and Hess, W.M., eds., Natural history of the Colorado Plateau and Great Basin: Niwot, Colo., University Press of Colorado, p. 163-208.

Sigler, W.F., 1951a, Age and growth of brown trout, Salmo trutta fario (Linnaeus), in Logan River, Utah: Transactions of the American Fisheries Society, v. 81, p. 171-178.

1951b, Life history and management of the mountain whitefish, Prosopium williamsoni (Girard) in Logan River, Utah: Utah State Agricultural College Bulletin, v. 347, p. 1-21.

1955, An ecological approach to understanding Utah's carp populations, in Harrison, G.L., ed., Proceedings of the Utah Academy of Sciences, Arts and Letters, v. 32, p. 95-104.

1958, The ecology and use of carp in Utah: Utah State University Agricultural Experiment Station Bulletin, v. 405, p. 1-63.

Sigler, W.F., and Miller, R.R., 1963, Fishes of Utah: Salt Lake City, Utah, Utah State Department of Fish and Game, 203 p.
Sigler, W.F., and Sigler, J.W., 1987, Fishes of the Great Basin, a natural history: University of Nevada Press, Reno, Nev. 425 p.

1996, Fishes of Utah: a natural history: Salt Lake City, Utah, University of Utah Press, 375 p.

Simpson, J.C., and Wallace, R.L., 1982, Fishes of Idaho: Moscow, Idaho, University Press of Idaho, $238 \mathrm{p}$.

Smart, E.W., 1958, An ecological study of the bottom fauna of Bear Lake, Idaho and Utah: Logan, Utah, Utah State University, Ph.D. dissertation, $42 \mathrm{p}$.

Smith, G.R., 1959, Effects of pollution on the Weber River, Utah: Salt Lake City, University of Utah, Master of Science thesis, $114 \mathrm{p}$.

Smith, M.E., and Maderak, M.L., 1993, Geomorphic and hydrologic assessment of the Bear River in and near Evanston, Wyoming: U.S. Geological Survey Water-Resources Investigations Report 93-4032, Cheyenne, Wyo., 45 p.

Snyder, J.O., 1924, Notes on certain Catostomids of the Bonneville system, including the type Pantosteus virescens (Cope): Proc. U.S. Nat. Mus., v. 64, p. 1-6.

Squires, L.E., 1977, Algal response to a thermal effluent: study of a power station on the Provo River, Utah: Provo, Utah, Brigham Young University, Ph.D. dissertation, $60 \mathrm{p}$.

Stephens, D.W., 1969, The physical and chemical environmental requirements of Trichoptera in the Weber River, Utah: Salt Lake City, University of Utah, Master of Science thesis, $72 \mathrm{p}$. 1984, Water-quality investigations of the Jordan River, Salt Lake County, Utah, 1980-82: U.S. Geological Survey Water-Resources Investigations Report 84-4298, Salt Lake City, Utah, 45 p.

Stephens, D.W., and Gerner, L.G., 1996, Utah, Wetland Resources: U.S. Geological Survey Water-Supply Paper 2425, Washington, D.C.

Tanner, V.M., 1932, A description of Notolepidomyzon utahensis, a new catostomid from Utah: Copeia, v. 2, p. 135-136.

1936, A study of the fishes of Utah: Utah Academy of Sciences, Arts and Letters, v. 13, p. 155183.

Thompson, K.R., 1983, Reconnaissance of the quality of surface water in the Weber River basin, Utah: Utah Department of Natural Resources Technical Publication No. 76.

1984, Reconnaissance of toxic substances in the Jordan River, Salt Lake County, Utah: U.S. Geo- 
logical Survey Water-Resources Investigations Report 84-4155, 31 p.

Toline, C.A., and Seitz, A.M., 1999, Mitochondrial and nuclear DNA variation within and among populations of Columbia spotted frog (Rana luteiventris) in Utah: Utah State University, Department of Fish and Wildlife, Logan, Utah, 73 p.

Trotter, P.C., and Bisson, P.A., 1988, History of the discovery of the cutthroat trout, in Gresswell, R.E., ed., Status and management of interior stocks of cutthroat trout: American Fisheries Society Symposium, v. 4, p. 8-12.

U.S. Bureau of Reclamation, 1995, Evaluation of dissolved oxygen enhancement upon trout and macroinvertebrate populations below Deer Creek Dam, Provo River, Utah: Utah Division of Wildlife Resources, Contract 4-FC-40-16050, Salt Lake City, Utah, 18 p.

U.S. Environmental Protection Agency, 1973, Jordan River Study, Utah, June-August 1972: Report S\&A/TSB-16, Technical Support Branch, Surveillance and Analysis Division, Region 8, Denver, Colo., 67 p.

U.S. Fish and Wildlife Service, 1986, Endangered and threatened wildlife and plants; final rule determining June sucker (Chasmistes liorus) to be an endangered species with critical habitat: Federal Register, v. 51, no. 61, p. 10851-10857.

_ 1995a, June sucker (Chasmistes liorus) recovery plan: Salt Lake City, Utah, 55 p.

1995b, Proposal to determine the least chub (Iotichthys phlegethontis) an endangered species with critical habitat: Federal Register, v. 60, no. 189, September 29, 1995, p. 50518-50530.

1998, Conservation agreement for spotted frog: Salt Lake City, Utah, 18 p.

U.S. Forest Service, 1994, Conservation agreement, Bonneville cutthroat trout, Thomas Fork drainage: Caribou National Forest, Pocatello, Idaho, 14 p.

Utah Department of Environmental Quality, 1996, Water quality assessment report to Congress: Division of Water Quality, Salt Lake City, 153 p.

Utah Division of Wildlife Resources, 1957, The effects of the Provo River channelization program on Utah's wildlife resources: River Basins report, Project No. FW-5-R-1, 12 p.

1975a, Tentative fishery evaluation for Jordan River tributaries: Prepared for Salt Lake County Council of Governments, 208 study. 1975b, Aquatic environmental inventory summary: Provo River from Olmstead power plant to Deer Creek dam: Salt Lake City, Utah, 16 p.

1996, Draft conservation agreement and strategy for Bonneville cutthroat trout (Oncorynchus clarki utah) in the State of Utah: Salt Lake City, Utah, $75 \mathrm{p}$.

Waddell, B., and Coyner, J., 1990, Screening evaluation of biologically active elements and pesticides in Utah Lake wetlands proposed for a National Wildlife Refuge: U.S. Fish and Wildlife Service, Salt Lake City, Utah, 13 p.

Waddell, B., Dolling, J., Linner, S., Stephens, D., and Stephensen, S., 1990, A preliminary evaluation of contaminants at the Bear River Migratory Bird Refuge acquisitions: U.S. Fish and Wildlife Service, Salt Lake City, 21 p.

Waddell, B., and Stephenson, S., 1992, Supplemental sampling for trace elements in biota at proposed Utah Lake National Wildlife Refuge: U.S. Fish and Wildlife Service, Salt Lake City, Utah, 13 p.

Way, T.G., 1980, Fishery potential of the Jordan River as affected by wastewater treatment alternatives: Salt Lake City, University of Utah, Master of Science thesis, $135 \mathrm{p}$.

West, P.W., 1984, Wetland resources of Salt Lake County, Report update: Salt Lake County Department of Public Works, Division of Flood Control and Water Quality, Salt Lake City, 119 p.

Wheeler, C.A., 1997, Current distributions and distributional changes of fishes in Wyoming west of the continental divide: Laramie, Wyo., University of Wyoming, Master of Science thesis, $112 \mathrm{p}$.

White, R.G., 1974, Endemic whitefishes of Bear Lake, Utah-Idaho: a problem in systematics: Logan, Utah, Utah State University, Ph.D. dissertation, 209 p.

Whitney, R.F., 1951, A comparison of aquatic invertebrates of Red Butte and Emigration Creeks: Salt Lake City, University of Utah, Master of Science thesis, $55 \mathrm{p}$.

Wilson, K.W., Radant, R.D., and Coffeen, M., 1998, Current distribution and population abundance of leatherside chub (Gila copei) in the Heber Valley: Utah Division of Wildlife Resources Publication No. 98-13, Salt Lake City, Utah, 43 p.

Wilson, M.M., 1984, Effects of flood control work on fish habitat in the Weber River, in Archer, D.L., ed., Proceedings of the Bonneville Chapter of the American Fisheries Society, Utah State University, 
Logan, Utah, Feb. 8-9, 1984: Salt Lake City, Utah, v. 1984 , p. 103-108.

1987, Jordan River fisheries evaluation: Utah Division of Wildlife Resources, Salt Lake City, Utah, 24 p.

Winger, P.V., 1972, The effects of channelization and water impoundment on the macroinvertebrates in the Weber River, Summit County, Utah: Provo, Utah, Brigham Young University, Ph.D. dissertation, $112 \mathrm{p}$.

Winger, P.V., Peters, E.J., Donahoo, M.J., Barnes, H.R., and White, D.A., 1972, A checklist of macroinvertebrates of the Provo River, Utah: Great Basin Naturalist, v. 32.

Wullschleger, J., and Pettengill, T.D., 1993, Logan River fish population surveys; evaluation of special regulations: Utah Division of Wildlife Resources, Salt Lake City, Utah, 14 p.

1994, Logan River cutthroat trout spawning study: Utah Division of Wildlife Resources, Salt Lake City, Utah, 7 p.

Wurtsbaugh, W.A., 1998, Bear Lake's trophic status and food web: A review of the effects of Bear River diversions: Report for Ecological Consultants for the Public Interest, North Logan, Utah, 17 p.

Wurtsbaugh, W.A., and Hawkins, C.P., 1990, Trophic interactions between fish and invertebrates in Bear
Lake, Utah-Idaho: Utah State University Ecology Center, Special Publication, Logan, Utah, 167 p.

Wurtsbaugh, W.A., and Luecke, C., 1994, Examination of the abundance and spatial distribution of forage fishes in Bear Lake: Utah Division of Wildlife Resources Progress Report, Project F-47-R, Study 5, Salt Lake City, Utah, 144 p.

Wurtsbaugh, W.A., and Neverman, D., 1988, Post-feeding thermotaxis and daily vertical migration in a larval fish: Nature, v. 333, p. 846-848.

Wydoski, R.S., and Helm, W.T., 1980, Effects of alterations to low gradient reaches of Utah streams: U.S. Fish and Wildlife Service, Biological Services Program, FWS/OBS-80/14, 159 p.

Young, M.K., 1995, Conservation assessment for inland cutthroat trout: U.S. Forest Service, Rocky Mountain Forest and Range Experiment Station, General Technical Report RM-256, Fort Collins, Colorado, $61 \mathrm{p}$.

Zarbock, W.M., 1951, Life history of the Utah sculpin, Cottus bairdi semiscaber (Cope), in Logan River, Utah: Transactions of the American Fisheries Society, v. 81, p. 249-259. 